\title{
Evolutionary Turnover in Wnt Gene Expression but Conservation of Wnt Signaling during Ovary Determination in a TSD Reptile
}

\author{
Turk Rhen Zachary Even Alaina Brenner Alexandra Lodewyk Debojyoti Das \\ Sunil Singh Rebecca Simmons \\ Department of Biology, University of North Dakota, Grand Forks, ND, USA
}

\section{Keywords}

Evolution · Selection - Temperature-dependent sex

determination $\cdot$ Wnt signaling

\begin{abstract}
Temperature-dependent sex determination (TSD) is a wellknown characteristic of many reptilian species. However, the molecular processes linking ambient temperature to determination of gonad fate remain hazy. Here, we test the hypothesis that Wnt expression and signaling differ between female- and male-producing temperatures in the snapping turtle Chelydra serpentina. Canonical Wnt signaling involves secretion of glycoproteins called WNTs, which bind to and activate membrane bound receptors that trigger $\beta$-catenin stabilization and translocation to the nucleus where $\beta$-catenin interacts with TCF/LEF transcription factors to regulate expression of Wnt targets. Non-canonical Wnt signaling occurs via 2 pathways that are independent of $\beta$-catenin: one involves intracellular calcium release (the $\mathrm{Wnt} / \mathrm{Ca}^{2+}$ pathway), while the other involves activation of RAC1, JNK, and RHOA (the Wnt/planar cell polarity pathway). We screened 20 Wnt genes for differential expression between female- and male-producing temperatures during sex deter-
\end{abstract}

karger@karger.com

(c) 2021 S. Karger AG, Basel

www.karger.com/sxd

Karger! mination in the snapping turtle. Exposure of embryos to the female-producing temperature decreased expression of 7 Wnt genes but increased expression of 2 Wnt genes and Rspo 1 relative to embryos at the male-producing temperature. Temperature also regulated expression of putative Wnt target genes in vivo and a canonical Wnt reporter (6x TCF/ LEF sites drive H2B-GFP expression) in embryonic gonadal cells in vitro. Results indicate that Wnt signaling was higher at the female- than at the male-producing temperature. Evolutionary analyses of all $20 \mathrm{Wnt}$ genes revealed that thermosensitive Wnts, as opposed to insensitive Wnts, were less likely to show evidence of positive selection and experienced stronger purifying selection within TSD species.

(c) 2021 S. Karger AG, Basel

\section{Introduction}

The gonadal primordium in vertebrates is unique in that it has the potential to develop into 2 distinct organs, the ovary or the testis [Devlin and Nagahama, 2002; Morrish and Sinclair, 2002]. In amniotes, this primordium initially develops as a ridge of tissue on the ventral surface of the embryonic mesonephros and is composed of 2 
parts, the coelomic epithelium and underlying mesenchymal cells [Witschi, 1951; Raynaud and Pieau, 1985; Wibbels et al., 1991; Smith and Joss, 1993; Merchant-Larios et al., 1997; Greenbaum and Carr, 2001; Morrish and Sinclair, 2002; Wilhelm et al., 2007]. These cells proliferate, increasing the size of the primordium, and begin to rearrange themselves to produce primary sex cords beneath the coelomic epithelium. It is at this stage that primordial germ cells finish their migration from the yolk sac and enter the gonad [Hubert, 1971, 1976; Fujimoto et al., 1979]. The bipotential gonad then develops into an ovary when outer cell layers, including the coelomic epithelium and subcoelomic mesoderm, begin to thicken into a distinct ovarian cortex, while the primary sex cords disintegrate and the inner medullary region regresses and eventually disappears [Loffler and Koopman, 2002]. In contrast, the bipotential gonad becomes a testis with further development of primary sex cords into seminiferous tubules, formation of the tunica albuginea, and septation of seminiferous tubes into lobules [Sekido and LovellBadge, 2013]. The tunica albuginea separates the medullary compartment from the coelomic epithelium, which does not develop any further in the testis.

While this basic pattern of gonadogenesis and morphogenesis of ovaries and testes is largely conserved across amniotes, other aspects of gonad development have diverged. The mechanism that determines the fate of the bipotential gonad is the most dramatic example of evolutionary divergence. Primary sex-determining mechanisms in amniotes include male heterogamety (XX females and XY males), female heterogamety (ZW females and $\mathrm{ZZ}$ males), genotypic sex determination without distinct sex chromosomes, and temperature-dependent sex determination (TSD) [Bachtrog et al., 2014; Capel, 2017]. The phylogenetic distribution of these sex-determining mechanisms in amniotes suggests TSD was the ancestral state [Pokorna and Kratochvil, 2016]. Indeed, many reptiles, including all crocodilians, most turtles, some lizards, and the tuatara, have TSD [Bull, 1980; Janzen and Paukstis, 1991; Valenzuela, 2004].

Since the discovery of TSD, a major goal has been to identify the mechanism(s) that transduces temperature into a molecular signal for ovary versus testis determination. Significant progress has been made identifying genes that are differentially expressed between temperatures that produce females versus males in reptiles [MerchantLarios et al., 2010; Rhen and Schroeder, 2010; Czerwinski et al., 2016; Yatsu et al., 2016]. This includes Foxl2 and Sox9, which are markers of ovary and testis determination, respectively. We also know from experimental stud- ies that aromatase and estrogens play a role in mediating temperature effects on ovary determination in TSD species [Crews, 1996; Pieau and Dorizzi, 2004; Lance, 2009; Ramsey and Crews, 2009]. Administration of aromatase inhibitors to embryos during the sex-determining period increases the number of males produced at temperatures that normally produce females (or mixed sex ratios), while estrogens induce ovarian development at temperatures that normally produce males. Yet, temporal expression profiles in embryos shifted between male and female temperatures suggest that aromatase is downstream in the ovary-determining pathway [Rhen et al., 2007; Rhen and Schroeder, 2010]. Delayed responses to temperature shifts are also observed for Foxl2 and Sox9 [Rhen et al., 2007], indicating these genes, like aromatase, are downstream in the gene regulatory network for sex determination.

This leaves us searching for thermosensitive factors that play a role in regulating aromatase, Foxl2, and Sox9 expression in TSD species. There are hints that Wnt signaling could play that part, because temperature influences expression of 2 genes (Rspo1 and Wnt4) involved in Wnt signaling [Smith et al., 2008; Shoemaker and Crews, 2009] and pharmacological activation of $\beta$-catenin inhibits Sox9 expression at a male-producing temperature in a TSD turtle [Mork and Capel, 2013]. Furthermore, Wnt signaling is involved in sex determination in other vertebrates. In mice, mutation of individual genes involved in Wnt signaling (i.e., Wnt4, Rspo1, or Ctnnb1) causes partial female-to-male sex reversal [Vainio et al., 1999; Chassot et al., 2008; Liu et al., 2009]. Conversely, constitutive activation of $\beta$-catenin (encoded by Ctnnb1) causes complete male-to-female sex reversal [Maatouk et al., 2008]. Sex reversal with constitutive $\beta$-catenin is due in part to activation of Foxl 2 via TCF/LEF binding sites in the Foxl2 promoter [Li et al., 2017]. Other work shows Wnt signaling and Foxl2 are both required for normal ovarian development: individual knockouts of Foxl2 or Wnt4 cause partial sex reversal, while double knockout of both genes causes complete female-to-male sex reversal [Ottolenghi et al., 2007]. Thus, Foxl2 and canonical Wnt signaling have complementary roles in ovary determination in mice, including both the activation of ovarian genes and the repression of testicular genes like Sox9. The part non-canonical Wnt pathways play in sex determination in mammals is thought to be minimal [Tevosian, 2013; Pannetier et al., 2016], though these pathways do appear to be involved in germ cell migration [Chawengsaksophak et al., 2012].

There is experimental evidence that Wnt signaling might be involved in TSD, but results of gain-of-function 
and loss-of-function experiments are conflicting. On one hand, $\beta$-catenin activation by $\mathrm{LiCl}$ or GSK-XV causes downregulation of Sox 9 at a male-producing temperature in red-eared slider turtles [Mork and Capel, 2013]. On the other hand, Wnt inhibitors did not upregulate Sox9 or block cortical development at a female-producing temperature in this species [Mork and Capel, 2013]. The former result supports the idea that Wnt signaling is involved in ovary determination (via repression of Sox9), while the latter result is equivocal. One possibility is that Wnt signaling does not play a physiological role in ovary determination in TSD species. Another possibility is that Wnt inhibitors did not work in the turtle or that Wnt inhibition alone is not sufficient to derepress Sox9 expression at the female-producing temperature. In fact, it is likely that other factors, like estrogens, independently repress Sox9 at female-producing temperatures [Barske and Capel, 2010]. Thus, it remains a distinct possibility that Wnt signaling is involved in ovary determination at female-producing temperatures in TSD species. It also remains to be determined which of the $20 \mathrm{Wnt}$ ligands found in amniotes could be involved in mediating temperature effects on the bipotential gonads.

We therefore screened all $20 \mathrm{Wnt}$ genes and Rspo1 for differential expression between male- and female-producing temperatures during the sex-determining period in the snapping turtle, Chelydra serpentina. We also measured expression of putative Wnt targets and used a canonical Wnt pathway reporter to test the hypothesis that Wnt signaling is higher at a female- than at a male-producing temperature. Finally, we carried out evolutionary analyses of all $20 \mathrm{Wnt}$ genes to test whether there is a relationship between Wnt thermosensitivity in the snapping turtle and selection on Wnt amino acid sequences within TSD species.

\section{Materials and Methods}

\section{Embryos and Temperature Shift}

Eggs were collected from snapping turtle nests in northern Minnesota within $24 \mathrm{~h}$ of laying. Upon collection, eggs were transported to the animal quarters at the Department of Biology, University of North Dakota, washed with tepid water, and stored for less than 1 week at $20^{\circ} \mathrm{C}$ to allow embryos to develop enough for candling. Eggs were candled to determine embryo viability and to separate infertile eggs. Roughly equal numbers of viable eggs were assigned to treatment groups at random to control for clutch effects on thermosensitivity [Rhen and Lang, 1998]. Eggs were then placed into their respective containers in moist vermiculite and randomly placed into foam box incubators as previously described [Rhen and Lang, 1994].

Wnt Signaling and Evolution in TSD
Eggs were initially incubated at a male-producing temperature of $26.5^{\circ} \mathrm{C}$. Embryos from each clutch were periodically sampled to monitor the developmental stage [Yntema, 1968]. Once embryos reached stage 17 , about half of the eggs were shifted to a femaleproducing temperature of $31^{\circ} \mathrm{C}$ for a 6 -day period and then returned to $26.5^{\circ} \mathrm{C}$ while the other half of the eggs remained at $26.5^{\circ} \mathrm{C}$ throughout incubation. Snapping turtle embryos from this population are very sensitive to a 6-day exposure to $31^{\circ} \mathrm{C}$ at stage 17 , which produces $100 \%$ females [Rhen et al., 2015]. Hereafter, the masculinizing $26.5^{\circ} \mathrm{C}$ treatment is designated $26 \mathrm{C}$ whereas the feminizing $31^{\circ} \mathrm{C}$ temperature shift is referred to as 26-31-26C. A subset of eggs was left to hatch and gonads were examined to verify that $26 \mathrm{C}$ produced only males and $26-31-26 \mathrm{C}$ produced only females.

\section{Tissue Collection, RNA Extraction, and Synthesis of} Complementary DNA

Eggs were removed from incubators for tissue collection on days $1,2,3,4$, and 5 of the temperature shift (i.e., the window when bipotential gonads are most thermosensitive and sex is determined) [Rhen et al., 2015]. Eggs were opened and embryos were quickly staged and euthanized via rapid decapitation. Adrenalkidney-gonad (AKG) complexes were dissected from the embryo, placed in RNAlater ${ }^{\circledR}$ solution (Ambion, Austin, TX, USA), and stored at $-20^{\circ} \mathrm{C}$.

Embryonic gonads were subsequently micro-dissected from the AKG complexes before RNA extraction to measure gene expression in pure gonadal tissue. Total RNA was extracted from pairs of gonads using the PicoPure RNA Isolation Kit (Arcturus, Mountain View, CA, USA). We adapted the manufacturer's protocol for laser capture microdissection and RNA extraction to isolate embryonic gonadal RNA as described in Rhen et al. [2007]. This protocol included an on-column DNAse I treatment to remove genomic DNA. Total RNA concentration was quantified using a NanoDrop ND-1000 spectrophotometer (NanoDrop Technologies, Wilmington, DE, USA) and/or a Qubit 3 Fluorometer using the RNA High Sensitivity quantification kit (Invitrogen Corp., Carlsbad, CA, USA; Cat. No. 32852).

Total RNA had 260/280 absorbance ratios between 1.70 and 2.20. Average RNA concentration was $62.1 \mathrm{ng} / \mu \mathrm{L}$ on the NanoDrop, while average RNA concentration was $50.2 \mathrm{ng} / \mu \mathrm{L}$ on the Qubit 3. All RNA samples were diluted to the same final concentration of $5 \mathrm{ng} / \mu \mathrm{L}$ (150 ng total RNA in a final volume of $30 \mu \mathrm{L})$. Total RNA ( $5 \mathrm{ng}$ ) was tested for genomic DNA contamination via qPCR. A positive control (5 ng genomic DNA) amplified at a $\mathrm{Ct}$ value of 25, while RNA samples and a negative control (filtered water) did not amplify at all or amplified very late $(>34 \mathrm{Ct})$. This indicated no (or miniscule) genomic DNA contamination in total RNA.

Total RNA (100 ng) from each sample was reverse transcribed in $20 \mu \mathrm{L}$ reaction volumes using the Applied Biosystems High Capacity cDNA Reverse Transcription kit according to the manufacturer's protocol (Thermo Fisher Scientific, Waltham, MA, USA; Cat. No. 4368814). Reactions employed random primers and incubation at $25^{\circ} \mathrm{C}$ for $10 \mathrm{~min}, 37^{\circ} \mathrm{C}$ for $2 \mathrm{~h}, 85^{\circ} \mathrm{C}$ for $5 \mathrm{~min}$, and a $4^{\circ} \mathrm{C}$ hold until samples were retrieved from a Bio-Rad iCycler (Bio-Rad Laboratories, Hercules, CA, USA). After reverse transcription, cDNA was diluted to a final working concentration of $1.25 \mathrm{ng}$ input $\mathrm{RNA} / \mu \mathrm{L}$ for subsequent gene expression analyses. 
Standard Curves for Measuring Gene Expression via qPCR

Primers for all 20 Wnt genes (Wnt1, Wnt2, Wnt2b, Wnt3a, Wnt3b, Wnt4, Wnt5a, Wnt5b, Wnt6, Wnt7a, Wnt7b, Wnt8a, Wnt8b, Wnt9a, Wnt9b, Wnt10a, Wnt10b, Wnt11, Wnt11b, and Wnt16) and Rspo1 were designed to hybridize to cDNA sequences retrieved from the snapping turtle genome [Das et al., 2020]. We measured Foxl2 and Sox 9 expression as positive controls for the temperature shift paradigm [Rhen et al., 2007]. We also designed primers to genes known to be Wnt targets in other species: Axin2, Btrc, and Vcan [Spiegelman et al., 2000; Jho et al., 2002; Willert et al., 2002; Rahmani et al., 2005]. In addition, Axin2, Btrc, and Dkk3 were selected because they regulate canonical Wnt signaling and could be part of autoregulatory feedback loops. We examined Osr 1 because it is a potential new marker for pre-granulosa cells and is co-expressed with Wnt4 during sex determination in chicken embryos [Estermann et al., 2020] and because OSR1 appears to be a Wnt target during induction of bipotential gonad cells from human embryonic stem cells [Sepponen et al., 2017] as well as in human fibroblasts [Klapholz-Brown et al., 2007]. Primers were purchased from Integrated DNA Technologies (Coralville, IA, USA). PCRs with melt-curve analyses were performed to verify the specificity of primers (i.e., each primer pair amplified just 1 PCR product). PCR products for each gene were purified using the Zymo Research DNA Clean \& Concentrator ${ }^{\mathrm{TM}}-5$ Kit (Zymo Research, Irvine, CA, USA; Cat. No. D4013). Purified PCR products were diluted to produce rigorous standard curves to quantify expression in absolute terms of attograms (ag) cDNA/2.5 ng of total RNA input. Standard curves spanned 8 orders of magnitude from 2,000,000 ag/tube, 200,000 ag/tube, 20,000 ag/tube, 2,000 ag/tube, $200 \mathrm{ag} /$ tube, $20 \mathrm{ag} /$ tube, $2 \mathrm{ag} / \mathrm{tube}$, and $0.2 \mathrm{ag} /$ tube as previously described [Rhen et al., 2007].

Quantitative PCR was carried out in $10 \mu \mathrm{L}$ reaction volumes comprised of $5 \mu \mathrm{L}$ of $2 \times$ SsoFast EvaGreen Supermix PCR Master Mix solution (Bio-Rad Laboratories; Cat. No. 1725204), $0.3 \mu \mathrm{L}$ of each forward and reverse primer (= $300 \mathrm{nM}$ final primer concentration), $2 \mu \mathrm{L}$ of cDNA (= $2.5 \mathrm{ng}$ of total RNA input), and $2.4 \mu \mathrm{L}$ of filtered Milli-Q water. Quantitative PCR included enzyme activation at $95^{\circ} \mathrm{C}$ for $30 \mathrm{~s}$ and 40 cycles of a 2 -step PCR $\left(95^{\circ} \mathrm{C}\right.$ for $5 \mathrm{~s}$ and $60^{\circ} \mathrm{C}$ for $5 \mathrm{~s}$ ) on a BioRad CFX384 thermocycler.

\section{Transfection Optimization}

We developed a protocol to transfect plasmids into dissociated turtle gonadal cells in vitro to monitor canonical Wnt signaling with a reporter plasmid. We first dissected gonads from embryos under sterile conditions and washed them in sterile $1 \times$ PBS. Gonads were pooled and dissociated using Liberase DH $(18 \mu \mathrm{L})$ and TM $(18$ $\mu \mathrm{L}$ ) enzymes in $2.5 \mathrm{~mL}$ of sterile $1 \times \mathrm{PBS}$ with periodic pipetting for $1 \mathrm{~h}$ until cells were completely disassociated. The cell suspension was centrifuged, supernatant removed, and cells resuspended in nucleofection buffer. The number of gonads pooled and the volume of nucleofection buffer are described below for each experiment.

For initial optimization of transfection, we used the Lonza 4D Nucleofector system to transfect plasmids into primary gonad cells from snapping turtle embryos. Optimal nucleofection programs were determined using the P3 Optimization kit and a range of settings suggested by the manufacturer. Approximately 2.4 million dissociated gonad cells were resuspended in $334 \mu \mathrm{L}$ of nucleofection buffer $(263 \mu \mathrm{L}$ P3 solution, $58 \mu \mathrm{L}$ of Supplement $1,6.4 \mu \mathrm{L}$ of pmaxGFP ${ }^{\mathrm{TM}}$ plasmid $[1 \mu \mathrm{g} / \mu \mathrm{L}]$, and $6.4 \mu \mathrm{L}$ of pEF1a-mCherry-N1 plasmid $[1.89 \mu \mathrm{g} / \mathrm{mL}])$. The GFP and mCherry vectors were used because they contain different promoters, CMV and human EF1 $\alpha$, which are constitutively active in mammalian cells. We did not know beforehand whether these promoters would drive reporter expression in turtle cells. After cell resuspension, $20 \mu \mathrm{L}$ of nucleofection buffer (about 150,000 cells) was transferred into each well of a 16-well Nucleocuvette strip.

An initial set of 15 nucleofection programs was tested, including CA-137, CM-138, CM-137, CM-150, DN-100, DS-138, DS137, DS-130, DS-150, DS-120, EH-100, EO-100, EN-138, EN-150, and EW-113 (programs were suggested by the manufacturer). Lonza does not provide details regarding variables in their nucleofection programs, but electroporation variables generally include voltage, pulse length, and number of pulses. One well in the strip contained cells but received no electrical shock (negative control). The Nucleocuvette strip was removed from the instrument after nucleofection and cells were allowed to recover for $10 \mathrm{~min}$ at room temperature. We used $100 \mu \mathrm{L}$ of pre-warmed L-15 medium to resuspend nucleofected cells in each well by gently pipetting up and down for 3 times. L-15 media contained 10\% charcoal-stripped fetal bovine serum and $1 \%$ antibiotic/antimycotic solution (penicillin, streptomycin, and amphotericin; Sigma A5955). The entire $120 \mu \mathrm{L}$ volume from each nucleofection program was plated in separate wells containing $480 \mu \mathrm{L}$ of L-15 media on a 24 -well TPP Tissue Culture plate ( $600 \mu \mathrm{L}$ total volume)

The plate was sealed in a sterile Ziploc bag and placed in the same type of incubator used for the eggs. Nucleofected cells were cultured at $26.5^{\circ} \mathrm{C}$ for $24 \mathrm{~h}$. Cells were observed and digital images were captured using an inverted fluorescence microscope. Nucleofection programs DS-150 and EW-113 were determined to be optimal based on the strength of fluorescence, transfection efficiency (i.e., the highest percentage of cells expressing the reporters; average transfection efficiency was $18.6 \%$ for DS-150), and the observation that more cell types with different morphologies were transfected using these programs. Additional testing revealed DS-150 performed better than EW-113, so program DS-150 was used in subsequent experiments.

\section{Expression of Wht Reporter in Gonadal Cells after Sex}

Determination

Gonads were micro-dissected from 40 presumptive female (incubated at $31^{\circ} \mathrm{C}$ during the temperature sensitive period) and 40 presumptive male embryos (incubated at $26.5^{\circ} \mathrm{C}$ during the temperature sensitive period) at Yntema stage 20.3, which is the end of the sex-determining period. Gonads were pooled by sex and kept separate for the rest of the procedure.

Presumptive ovaries and presumptive testes were digested separately using Liberase $\mathrm{DH}(18 \mu \mathrm{L})$ and TM $(18 \mu \mathrm{L})$ enzymes in 2.5 $\mathrm{mL}$ of sterile $1 \times \mathrm{PBS}$ with periodic pipetting for about $1 \mathrm{~h}$ until cells were disassociated. The concentration of cells was determined using a Coulter counter. Roughly 800,000 cells were centrifuged for $10 \mathrm{~min}$, and the supernatant was removed and discarded. Ovarian and testicular cells were each resuspended using $91.7 \mu \mathrm{L}$ of nucleofection buffer (half of a master mix containing 147.6 $\mu \mathrm{L}$ P3 solution, $32.4 \mu \mathrm{L}$ of Supplement 1 , and $3.38 \mu \mathrm{L}$ of a Wnt reporter $[2 \mu \mathrm{L} /$ $\mu L])$. We used the TCF/LEF:H2B-GFP plasmid described by Ferrer-Vaquer et al. [2010]. This reporter has 6 copies of a TCF/LEF response element next to a minimal promoter that drives expression of a human histone $\mathrm{H} 2 \mathrm{~B}-\mathrm{GFP}$ fusion protein.

After resuspension, $20 \mu \mathrm{L}$ (about 200,000 cells) of nucleofection buffer containing ovarian or testicular cells was placed into 4 
Table 1. Results from aBSREL analyses of Wnt genes in vertebrates

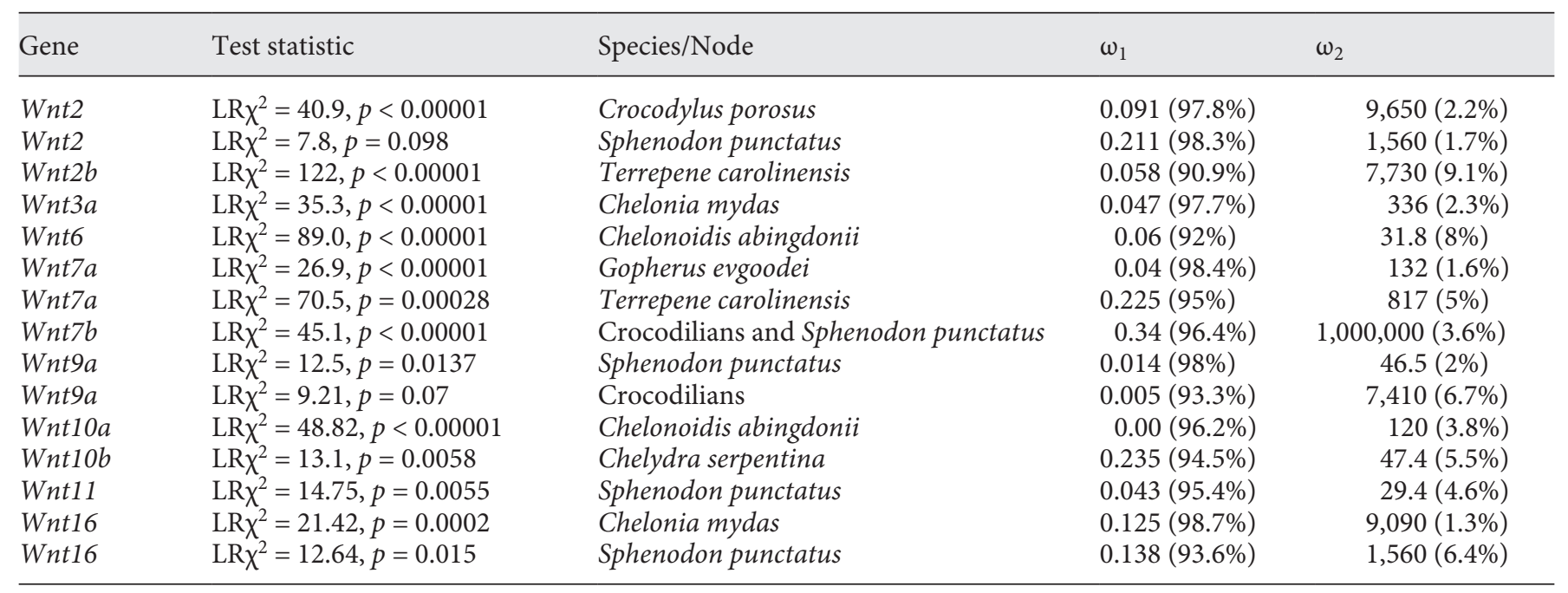

Species with TSD were designated as foreground branches, while non-TSD species were designated as background branches. Tests were performed at each branch to compare the full model (allowing positive selection) to the null model where branches were not allowed to have rate classes of $\omega>1$. aBSREL infers the optimal number of rate classes on each foreground branch and calculates the average value for each significant $\omega_{\mathrm{N}}$. Probability values were corrected for multiple testing.

separate wells ( 2 sexes $\times 4$ wells/sex $=8$ wells total) on a Nucleocuvette strip. Cells were nucleofected with program DS-150, allowed to recover, and plated using the optimal protocol described above. Female and male cells were plated on separate 24 -well plates. Female cells were returned to the $31^{\circ} \mathrm{C}$ incubator for 2 days, while male cells were returned to the $26.5^{\circ} \mathrm{C}$ incubator for 2 days. Cells were then observed and images captured using an inverted fluorescence microscope to semi-quantitatively measure expression of H2B-GFP. We used exactly the same settings for capturing all images to allow comparison of fluorescence between dissociated ovarian and testicular cells (see quantification method below).

\section{Temperature Effects on Expression of a Wnt Reporter in} Bipotential Gonad Cells

We dissected 25 embryos to collect bipotential gonads for another study using the Wnt reporter. Embryos were incubated at $26.5^{\circ} \mathrm{C}$ throughout development and dissected at Yntema stage 18.5 (during the thermosensitive period). Gonad cells were disassociated as described above. The solution was centrifuged, and the supernatant was removed. Cells were resuspended in $61.1 \mu \mathrm{L}$ of nucleofection buffer (49.2 $\mu \mathrm{L}$ P3 solution, $10.8 \mu \mathrm{L}$ of Supplement 1 , and $1.125 \mu \mathrm{L}$ of Wnt reporter $[2 \mu \mathrm{g} / \mu \mathrm{L}])$. After resuspension, 20 $\mu \mathrm{L}$ nucleofection buffer containing about 200,000 bipotential cells were placed into 2 wells on a Nucleocuvette strip (replicate transfections). Cells were nucleofected with program DS-150 and allowed to recover for $10 \mathrm{~min}$.

We used $100 \mu \mathrm{L}$ of pre-warmed L-15 medium to resuspend nucleofected cells in each well by gently pipetting up and down for 3 times. The $120 \mu \mathrm{L}$ volume from each well was split in half $(2 \times 60$ $\mu \mathrm{L}$ aliquots) and plated in $540 \mu \mathrm{L} \mathrm{L}-15$ media on two 24 -well plates (600 $\mathrm{LL}$ total volume). One plate was placed in a $31^{\circ} \mathrm{C}$ incubator while the other was placed in a $24^{\circ} \mathrm{C}$ incubator to mimic in vivo temperature shifts. Thus, bipotential gonads were dissociated to- gether and then split into 2 batches of cells that were transfected in an identical manner. Each batch of transfected cells was split in half and exposed to female or male temperatures ( 2 batches $\mathrm{x} 2$ temperatures $=4$ wells total). Images of cells were captured at 2 and 4 days of incubation at 24 or $31^{\circ} \mathrm{C}$ (equivalent to days 2 and 4 of in vivo temperature shifts).

\section{Image Capture and Processing (Corrected Total Cell \\ Fluorescence)}

We first identified the brightest cell within an experiment by visual inspection on an Olympus CK2 Inverted Microscope. Images were captured using a Hamamatsu digital camera (8-bit, 256 intensity levels) and Simple PCI imaging software. Exposure was adjusted so the brightest cell almost saturated the detector as described by Brown [2007]. Every image within an experiment was captured using exactly the same settings. In the experiment using ovarian and testicular cells after sex determination, we captured images of cells in 3 regions in each well (left, center, and right along the horizontal transect through the center of the wells). In the experiment with primary cells from bipotential gonads, we captured images of cells in 5 regions in each well (left, center, right, top, bottom). We also captured brightfield images for every region before moving to the next region in order to count total cells within an image.

Images were imported into Image $\mathrm{J}^{\circledR}$, which was used to measure total cell fluorescence and the area of the selected cell. Every cell with fluorescence above background was measured. Mean background was calculated for 5 randomly selected spots that were the same size as an average cell in each image. The total number of cells in each region was counted in brightfield images. Corrected total cell fluorescence (CTCF) was calculated using the formula:

$\mathrm{CTCF}=$ total cell fluorescence $-($ area of the cell $\times$ mean of the background fluorescence). 


\section{Statistical Analyses}

Data were analyzed using JMP 13.1.0 software (SAS Institute, Cary, NC, USA). Gene expression was analyzed with 2-way, mixed model ANOVA. Temperature, sampling day, and the temperature $\times$ day interaction were fixed effects, and clutch identity was a random effect in restricted maximum likelihood (REML) ANOVA. Nested ANOVA was used to analyze CTCF in transfected cells. Temperature and well identity were main effects in the model. Region, nested within well, was used to control for potential variation in light transmittance within wells. Transformations ( $\log _{10}$, square root) were used, when needed, to ensure each dependent variable met the assumptions of ANOVA. Different transformations were used for different genes as shown in Table 1. Comparisons were only made between experimental groups within a given gene but did not compare expression between genes. Means were backtransformed for presentation in figures.

\section{Comparative Analysis of Wnt Expression in Embryonic}

Gonads

We retrieved gene expression values for 19 Wnt ligands (Wnt11b has been lost in mammals) in ovaries and testes from embryonic humans using the EMBL Gene Expression Atlas (https://www.ebi.ac.uk/gxa/home). These data were originally published as part of a larger study that compared gene expression patterns in several organs across the lifespan of humans and other mammals [Cardoso-Moreira et al., 2020]. We specifically retrieved expression data from normal ovaries and testes at weeks $6,7,8$, and 9 of gestation, which encompasses the sex-determining period in humans. Expression values in this database are reported as transcripts per million (TPM), with isoforms collapsed into a single gene model. We separately calculated average ovarian expression for each Wnt gene and average testicular expression of each Wnt gene during the sex-determining period. We also calculated the average across both sexes for each gene as an overall index of gene expression in human embryonic gonads. Overall gonadal, ovarian, and testicular expression values in humans were then correlated with the corresponding expression values for orthologous genes in turtle gonads. That is, human WNT1 expression was paired with turtle Wnt1 expression, human WNT2 was paired with turtle $W n t 2$, human WNT3 is paired with turtle Wnt3, and so on. There was a much wider range between Wnt genes with the lowest versus highest expression in snapping turtle (absolute expression) versus human (relative expression) with a 14,478-fold difference versus a 626 -fold difference, respectively. In addition, when we examined histograms of expression values for the 19 Wnt genes in humans and the $20 \mathrm{Wnt}$ genes in turtles, the distributions were not normal. The distribution of Wnt expression values was skewed to the right in both species. To achieve bivariate normality, we $\log _{10}$ transformed expression values from both species to calculate correlations and to make scatterplots.

\section{Analyses of Wnt Sequence Evolution}

We retrieved cDNA sequences for Wnt ligands from 259 vertebrate species, though not all Wnt ligands were found in each individual taxon (online suppl. Table 1; for online suppl. material, see www.karger.com/doi/10.1159/516973). These taxa included members of 5 of the 7 traditionally recognized vertebrate lineages: Class Osteichthyes (bony fishes), Class Amphibia (amphibians), Class Reptilia (reptiles), Class Aves (birds), and Class Mammalia (mammals). We aligned amino acid sequences for each Wnt ligand using CLUSTAL with the Blosum Model [Larkin et al., 2007] via the CIPRES portal [Miller et al., 2010]. We then back-translated the aligned amino acid sequences into aligned nucleotides using RevTrans 2.0 through the RevTrans $2.0 \mathrm{~b}$ server [Wernersson and Pederson, 2003]. We excluded cDNA sequences that were less than $85 \%$ of the full-length reading frame.

We uploaded files with aligned cDNAs for each Wnt gene to DataMonkey [Weaver et al., 2018] to test whether Wnt genes displayed evidence of diversifying selection over evolutionary time in TSD species. We will provide the trimmed, aligned sequences in fasta format upon request. We first used BUSTED to detect selection in each Wnt locus [Murrell et al., 2015]. We then examined each Wnt locus to find the position of amino acids under diversifying selection, setting $p<0.05$ to determine significance [Smith et al., 2015]. We also compared TSD versus GSD lineages using aBSREL, using default settings, to determine if TSD linages experienced differential rates of selection [Smith et al., 2015]. We selected the following species, along with connecting internal nodes, as "test branches" to determine the presence of lineage specific, nonneutral rates of evolution: Alligator mississippiensis (American alligator), Alligator sinensis (Chinese alligator), Crocodylus porosus (Saltwater crocodile), Gavialis gangeticus (Gharial), Chelonia mydas (green sea turtle), C. serpentina (common snapping turtle), Chrysemys picta (painted turtle), Terrapene mexicana (Mexican box turtle), Trachemys scripta (red-eared slider), Terrapene carolina (common box turtle), Gopherus evgoodei (Sinaloan desert tortoise), Chelonoidis abingdonii (Pinta Island tortoise), and Sphenodon punctatus (Tuatura).

We also examined evolutionary relationships among the Wnt genes. We constructed a phylogenetic tree of Wnt loci using amino acid sequences for representative vertebrate species that had all loci represented in public databases or from this work: A. mississippiensis, C. serpentina, Coturnix japonica, Danio rerio, Gekko japonicus, Homo sapiens, Latimeria chalumnae, Monodelphis domestica, Python bivittatus, and Xenopus tropicalis. Amino acids were aligned using CLUSTAL with the JTT Model [Larkin et al., 2007] via the CIPRES portal [Miller et al., 2010], as specified by jModelTest2 [Guindon and Gascuel, 2003; Darriba et al., 2012]. Phylogenetic trees were constructed in RAXML with this model, using 1,000 bootstrap replications to assess nodal support [Stamatakis, 2014].

The mode of sex determination is almost completely confounded with the class for available Wnt sequences: all mammals and birds have GSD, all crocodilians have TSD, turtle Wnt sequences are almost entirely from TSD species (only 1 GSD species is available), and squamate Wnt sequences are only available for GSD species. We therefore compared evolutionary rates between thermosensitive Wnts versus insensitive Wnts in TSD species, as determined by the thermosensitivity observed in snapping turtle.

\section{Results}

\section{Temperature Effects on Expression of Positive Control} Genes and Putative Wnt Targets

Incubation temperature and the temperature-by-day interaction influenced expression of positive control genes Foxl2 and Sox9 (Table 2). Expression of Foxl2 in 
Table 2. Results from mixed model ANOVA for mRNA expression in gonads from embryonic snapping turtles using REML

\begin{tabular}{|c|c|c|c|}
\hline Gene & Temperature & Day & $\begin{array}{l}\text { Temperature-by-day } \\
\text { interaction }\end{array}$ \\
\hline Axin2 (sqrt) & $\mathrm{F}_{1,105}=48.67, p<0.0001$ & $\mathrm{~F}_{4,105}=2.87, p=0.026$ & $\mathrm{~F}_{4,105}=2.40, p=0.054$ \\
\hline Btrc & $\mathrm{F}_{1,104}=9.40, p=0.003$ & $\mathrm{~F}_{4,104}=0.57, p=0.68$ & $\mathrm{~F}_{4,104}=0.34, p=0.85$ \\
\hline$D k k 3\left(\log _{10}\right)$ & $\mathrm{F}_{1,104}=49.02, p<0.0001$ & $\mathrm{~F}_{4,104}=2.34, p=0.059$ & $\mathrm{~F}_{4,104}=1.54, p=0.20$ \\
\hline Foxl2 $\left(\log _{10}\right)$ & $\mathrm{F}_{1,70}=26.34, p<0.0001$ & $\mathrm{~F}_{4,70}=4.06, p=0.005$ & $\mathrm{~F}_{4,70}=5.61, p=0.0006$ \\
\hline Osr1 $\left(\log _{10}\right)$ & $\mathrm{F}_{1,69}=71.7, p<0.0001$ & $\mathrm{~F}_{4,69}=0.66, p=0.62$ & $\mathrm{~F}_{4,69}=2.59, p=0.04$ \\
\hline Rspo1 $\left(\log _{10}\right)$ & $\mathrm{F}_{1,69}=14.28, p=0.0003$ & $\mathrm{~F}_{4,69}=5.44, p=0.0007$ & $\mathrm{~F}_{4,69}=1.85, p=0.13$ \\
\hline Sox9 $\left(\log _{10}\right)$ & $\mathrm{F}_{1,63}=9.12, p=0.004$ & $\mathrm{~F}_{4,65}=1.18, p=0.33$ & $\mathrm{~F}_{4,63}=2.77, p=0.03$ \\
\hline Vcan (sqrt) & $\mathrm{F}_{1,104}=39.41, p<0.0001$ & $\mathrm{~F}_{4,104}=3.53, p=0.009$ & $\mathrm{~F}_{4,104}=1.14, p=0.34$ \\
\hline Wnt1 & $\mathrm{F}_{1,66}=5.45, p=0.02$ & $\mathrm{~F}_{4,68}=0.60, p=0.66$ & $\mathrm{~F}_{4,66}=0.72, p=0.58$ \\
\hline Wnt2 (sqrt) & $\mathrm{F}_{1,71}=0.99, p=0.32$ & $\mathrm{~F}_{4,71}=0.48, p=0.75$ & $\mathrm{~F}_{4,71}=1.83, p=0.13$ \\
\hline$W n t 2 b\left(\log _{10}\right)$ & $\mathrm{F}_{1,64}=13.22, p=0.0006$ & $\mathrm{~F}_{4,65}=0.73, p=0.58$ & $\mathrm{~F}_{4,64}=1.98, p=0.11$ \\
\hline Wnt3 & $\mathrm{F}_{1,69}=1.68, p=0.20$ & $\mathrm{~F}_{4,69}=0.60, p=0.67$ & $\mathrm{~F}_{4,69}=0.21, p=0.93$ \\
\hline Wnt3a $\left(\log _{10}\right)$ & $\mathrm{F}_{1,66}=2.55, p=0.16$ & $\mathrm{~F}_{4,68}=2.16, p=0.08$ & $\mathrm{~F}_{4,66}=0.87, p=0.48$ \\
\hline Wnt4 & $\mathrm{F}_{1,68}=5.64, p=0.02$ & $\mathrm{~F}_{4,68}=2.03, p=0.10$ & $\mathrm{~F}_{4,68}=1.30, p=0.28$ \\
\hline Wnt5a & $\mathrm{F}_{1,67}=6.34, p=0.01$ & $\mathrm{~F}_{4,69}=0.82, p=0.52$ & $\mathrm{~F}_{4,67}=0.52, p=0.72$ \\
\hline$W n t 5 b$ & $\mathrm{~F}_{1,71}=3.75, p=0.06$ & $\mathrm{~F}_{4,71}=0.40, p=0.81$ & $\mathrm{~F}_{4,71}=0.23, p=0.92$ \\
\hline Wnt6 & $\mathrm{F}_{1,67}=0.006, p=0.94$ & $\mathrm{~F}_{4,68}=1.18, p=0.32$ & $\mathrm{~F}_{4,67}=0.89, p=0.47$ \\
\hline$W n t 7 a$ & $\mathrm{~F}_{1,69}=24.81, p<0.0001$ & $\mathrm{~F}_{4,69}=2.26, p=0.07$ & $\mathrm{~F}_{4,69}=3.35, p=0.01$ \\
\hline$W n t 7 b$ & $\mathrm{~F}_{1,64}=1.12, p=0.29$ & $\mathrm{~F}_{4,64}=0.29, p=0.88$ & $\mathrm{~F}_{4,64}=0.71, p=0.58$ \\
\hline Wnt8a & $\mathrm{F}_{1,64}=9.08, p=0.004$ & $\mathrm{~F}_{4,66}=1.34, p=0.26$ & $\mathrm{~F}_{4,64}=0.61, p=0.66$ \\
\hline Wnt8b & $\mathrm{F}_{1,65}=0.83, p=0.36$ & $\mathrm{~F}_{4,67}=2.97, p=0.02$ & $\mathrm{~F}_{4,65}=0.67, p=0.62$ \\
\hline Wnt9a & $\mathrm{F}_{1,67}=2.30, p=0.13$ & $\mathrm{~F}_{4,69}=0.32, p=0.86$ & $\mathrm{~F}_{4,67}=0.22, p=0.92$ \\
\hline Wnt9b $\left(\log _{10}\right)$ & $\mathrm{F}_{1,61}=4.93, p=0.03$ & $\mathrm{~F}_{4,63}=6.05, p=0.0003$ & $\mathrm{~F}_{4,61}=0.17, p=0.95$ \\
\hline Wnt10a & $\mathrm{F}_{1,69}=0.0006, p=0.98$ & $\mathrm{~F}_{4,69}=1.01, p=0.41$ & $\mathrm{~F}_{4,69}=0.74, p=0.57$ \\
\hline Wnt10b & $\mathrm{F}_{1,67}=2.75, p=0.10$ & $\mathrm{~F}_{4,69}=0.18, p=0.95$ & $\mathrm{~F}_{4,67}=0.14, p=0.97$ \\
\hline Wnt11 (sqrt) & $\mathrm{F}_{1,69}=6.17, p=0.015$ & $\mathrm{~F}_{4,69}=0.83, p=0.51$ & $\mathrm{~F}_{4,69}=1.17, p=0.33$ \\
\hline Wnt11b $\left(\log _{10}\right)$ & $\mathrm{F}_{1,66}=2.00, p=0.16$ & $\mathrm{~F}_{4,67}=1.75, p=0.15$ & $\mathrm{~F}_{4,66}=5.08, p=0.001$ \\
\hline Wnt16 & $\mathrm{F}_{1,69}=0.16, p=0.69$ & $\mathrm{~F}_{4,69}=3.26, p=0.01$ & $\mathrm{~F}_{4,69}=1.48, p=0.22$ \\
\hline
\end{tabular}

Transformations were used when necessary to meet assumptions of ANOVA (shown in parentheses for each gene). Incubation temperature, sampling day, and the temperature-by-day interaction were fixed effects in the model. Clutch identity was a random effect in the model.

embryonic gonads increased significantly on days 3, 4, and 5 of the shift to $31^{\circ} \mathrm{C}$ but remained low in gonads of embryos kept at $26.5^{\circ} \mathrm{C}$ (Fig. 1a). Foxl2 expression was 6.7-fold higher at the female-producing temperature than at the male-producing temperature by day 5 of the shift. The opposite pattern was observed for Sox 9 expression, which remained constant in embryos at $26.5^{\circ} \mathrm{C}$ but decreased significantly in embryos at $31^{\circ} \mathrm{C}$ on days 4 and 5 of the shift (Fig. 1b). Sox 9 expression was 6 -fold higher at the male-producing temperature than at the female-producing temperature by day 5 of the shift. These findings mirror a prior temperature shift study [Rhen et al., 2007] and indicate that this experimental paradigm produces highly repeatable results.

To begin to test whether Wnt signaling was affected by temperature, we first measured expression of putative
Wnt targets. Temperature affected expression of all genes examined, including Axin2, Btrc, Dkk3, Osr1, and Vcan (Table 2). The temperature-by-day interaction for Axin 2 also approached significance (Table 2). Exposure of embryos to $31^{\circ} \mathrm{C}$ had no effect on day 1 but increased Axin 2 expression by 2.5 -fold on days $2-5$ of the shift when compared to gonads at $26.5^{\circ} \mathrm{C}$ (Fig. 1c). Temperature and the temperature-by-day interaction significantly influenced expression of Osrl, a new pre-granulosa cell marker and potential Wnt target. Expression of Osr1 increased on days $2,3,4$, and 5 of the shift to $31^{\circ} \mathrm{C}$ in snapping turtle embryos but did not change in gonads of embryos kept at $26.5^{\circ} \mathrm{C}$ (Fig. 1d). In contrast, expression of Btrc was 1.31fold higher in gonads at $26.5^{\circ} \mathrm{C}$ than gonads at $31^{\circ} \mathrm{C}$ (Fig. 2a). Stronger effects were observed for $D k k 3$ and Vcan, which were 1.74-fold and 1.92-fold higher at 26.5 

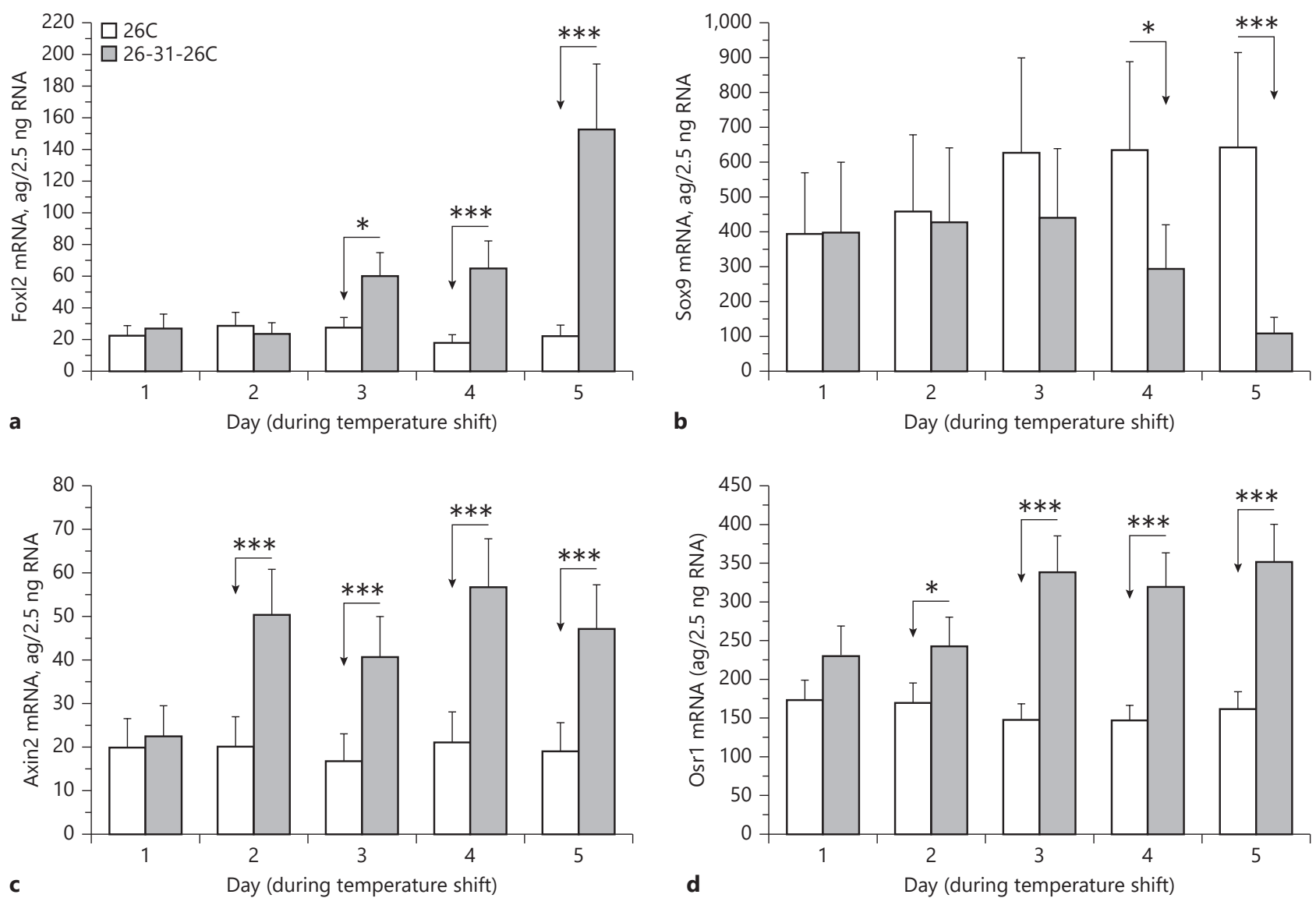

Fig. 1. Expression of Foxl2 (a), Sox9 (b), Axin2 (c), and Osr1 (d) mRNAs in embryonic snapping turtle gonads during the temperature sensitive period. Eggs were incubated at a male-producing temperature (26C) throughout embryogenesis or briefly shifted to a female-producing temperature (26-31-26C) when embryos reached stage 17 . Embryos were sampled at the indicated times

during the temperature shift. Expression levels are least squares means ( \pm 1 SE) for each temperature and time point. Arrows indicate significant differences between temperatures at the specified time, and asterisks indicate level of significance. ${ }^{*} p<0.05,{ }^{* *} p<$ $0.01,{ }^{* * *} p<0.001$.

than at $31^{\circ} \mathrm{C}$, respectively (Fig. $2 \mathrm{~b}, \mathrm{c}$ ). The temperature shift altered expression of several putative Wnt target genes, suggesting that temperature influences Wnt signaling.

Temperature Effects on Expression of a Wnt Reporter

To further test the hypothesis that temperature alters Wnt signaling, we measured temperature effects on expression of a canonical Wnt reporter transfected into embryonic gonadal cells. In the first experiment, all embryos were incubated at the same male-producing temperature $\left(26.5^{\circ} \mathrm{C}\right)$ until stage 18.5 (mid-late thermosensitive period in the snapping turtle). Bipotential gonads were then collected, dissociated, and cells transfected with the Wnt re-

porter in 2 batches. Transfected cells from each batch were evenly split between wells on 2 plates and then placed at a male $\left(24^{\circ} \mathrm{C}\right)$ or a female-producing temperature $\left(31^{\circ} \mathrm{C}\right)$ to mimic in vivo temperature shifts (i.e., embryos were incubated at the same male temperature until gonads were dissociated, cells transfected, plated, and then shifted to a female temperature or kept at a maleproducing temperature). Temperature significantly influenced expression of the Wnt reporter $\left(\mathrm{F}_{1,227}=14.8\right.$, $p=0.0002$ ), with greater CTCF in cells incubated for 2 days at the female temperature than in cells kept at a male temperature (Fig. 3a). Temperature also influenced the percentage of cells with detectable GFP expression 2 days after transfection $\left(\mathrm{F}_{1,16}=13.95, p=0.002\right)$, with a higher 


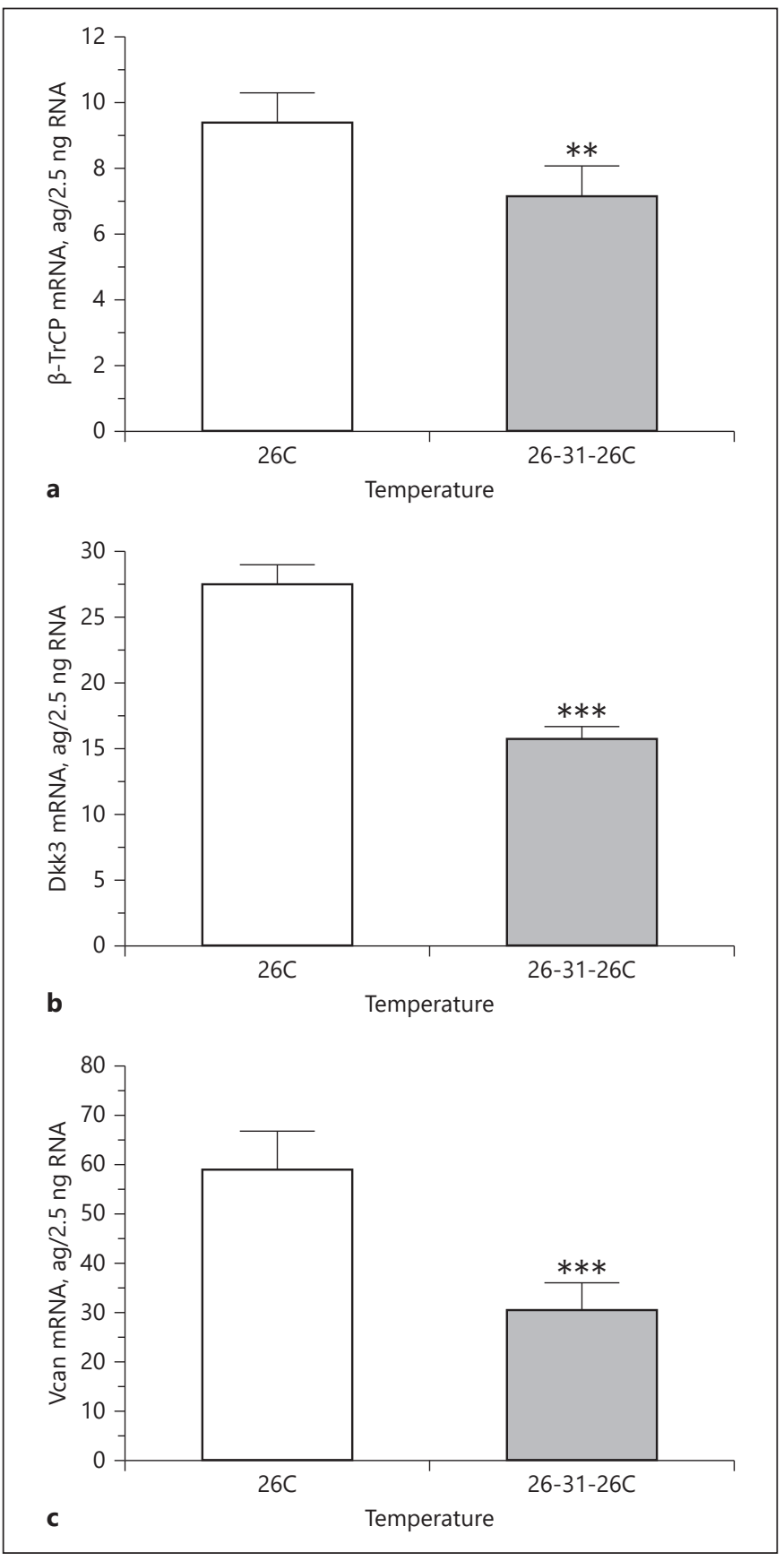

Fig. 2. Average expression of Wnt target genes beta-TrCP (a), $D k k 3$ (b), and Vcan (c) mRNAs in embryonic snapping turtle gonads during a 5-day temperature shift experiment. Eggs were incubated at a male-producing temperature (26C) throughout embryogenesis or shifted to a female-producing temperature (26-31$26 \mathrm{C})$ for 5 days when embryos reached stage 17. Expression was averaged across the 5-day temperature shift because there was no temperature-by-day interaction for these genes. Temperature significantly influences expression of all genes presented in this figure. Expression levels are least squares means $( \pm 1 \mathrm{SE})$ for each temperature. Asterisks indicate level of significance for temperature comparison. ${ }^{*} p<0.05,{ }^{* *} p<0.01,{ }^{* * *} p<0.001$.

Wnt Signaling and Evolution in TSD

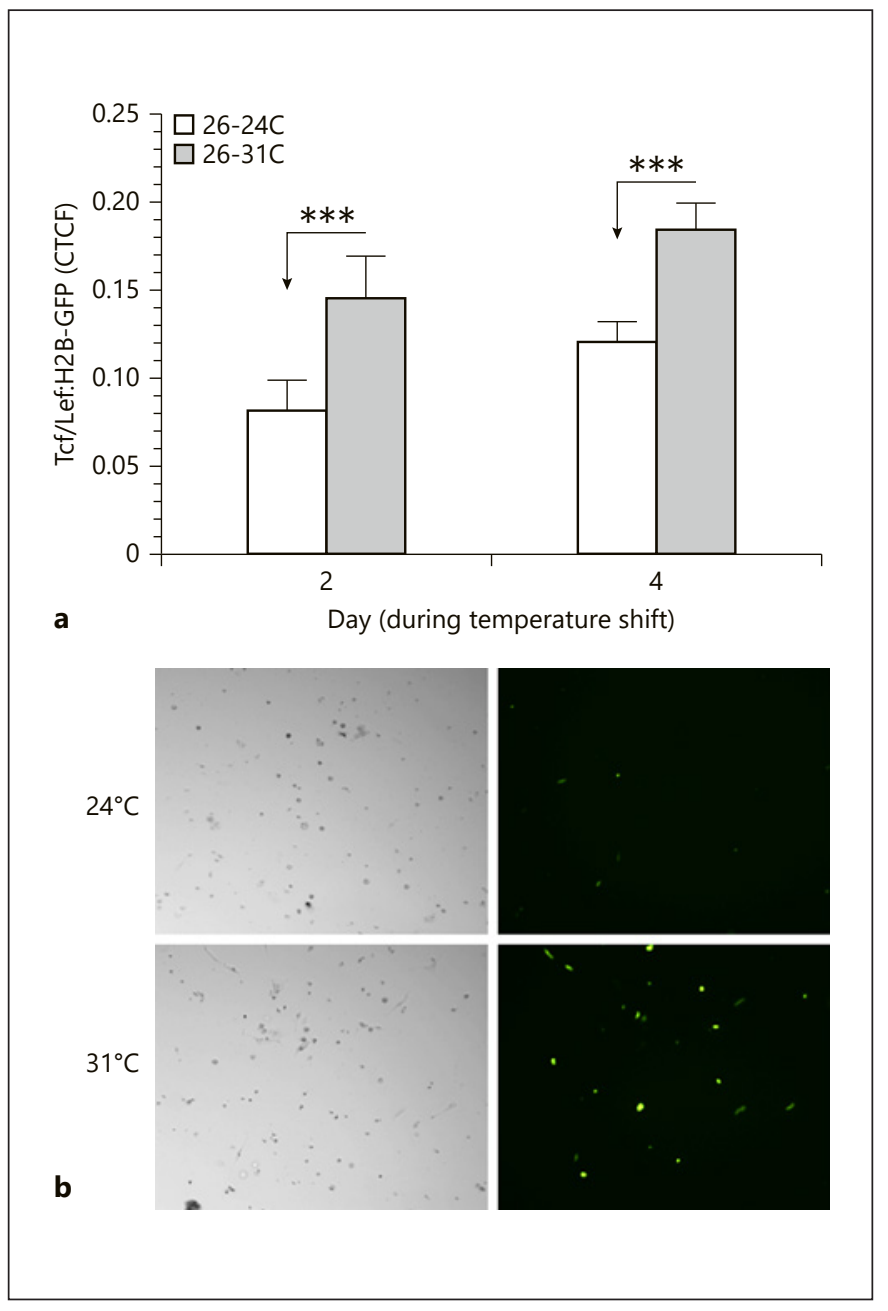

Fig. 3. Expression of a Wnt reporter plasmid (TCF/LEF:H2B-GFP) transiently transfected into primary cells from bipotential gonads of snapping turtles. Eggs were incubated at a male-producing temperature $\left(26.5^{\circ} \mathrm{C}\right)$ until embryos reached stage 18.5 when gonads were isolated and dissociated into individual cells. Cells were transfected with the Wnt reporter, plated into replicate wells, and then incubated at a male-producing temperature $\left(24^{\circ} \mathrm{C}\right)$ or a female temperature $\left(31^{\circ} \mathrm{C}\right)$. a Expression of the reporter was measured after 2 and 4 days at 24 and $31^{\circ} \mathrm{C}$. Expression was measured as corrected total cell fluorescence (CTCF) of the H2B:GFP fusion protein in individual GFP positive cells and reported as least squares means $( \pm 1 \mathrm{SE})$ for each temperature and time point. Arrows indicate significant differences between temperatures at the specified time, and asterisks indicate level of significance. b Representative brightfield and fluorescence images of transfected primary gonadal cells incubated at 24 or $31^{\circ} \mathrm{C}$ for 4 days. ${ }^{*} p<0.05$, ${ }^{* *} p<0.01,{ }^{* * *} p<0.001$. 

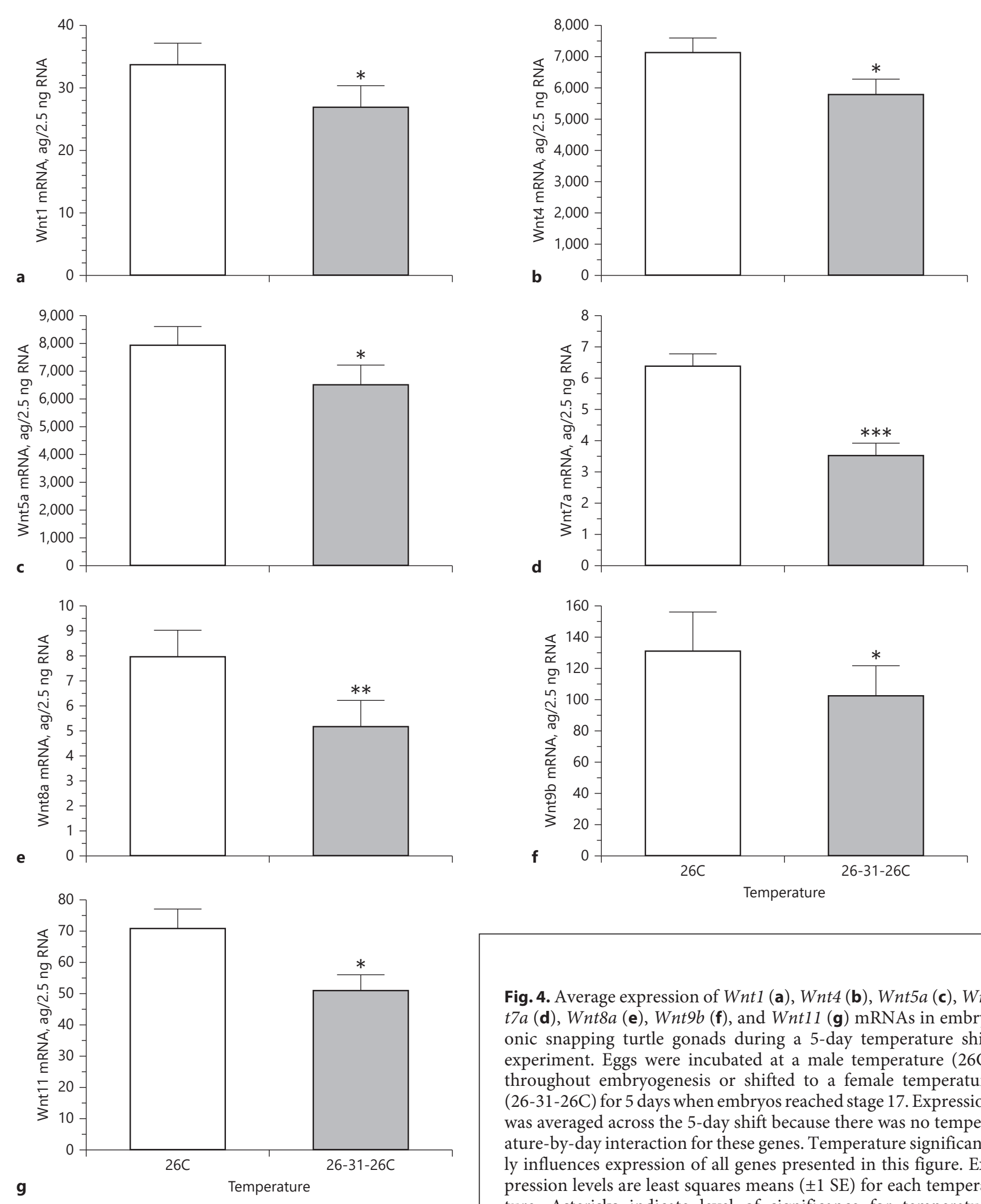

Fig. 4. Average expression of Wnt1 (a), Wnt4 (b), Wnt5a (c), Wn$t 7 a(\mathbf{d}), W n t 8 a(\mathbf{e}), W n t 9 b(\mathbf{f})$, and $W n t 11$ (g) mRNAs in embryonic snapping turtle gonads during a 5-day temperature shift experiment. Eggs were incubated at a male temperature (26C) throughout embryogenesis or shifted to a female temperature (26-31-26C) for 5 days when embryos reached stage 17. Expression was averaged across the 5-day shift because there was no temperature-by-day interaction for these genes. Temperature significantly influences expression of all genes presented in this figure. Expression levels are least squares means $( \pm 1 \mathrm{SE})$ for each temperature. Asterisks indicate level of significance for temperature comparison. ${ }^{*} p<0.05,{ }^{* *} p<0.01,{ }^{* * *} p<0.001$. 


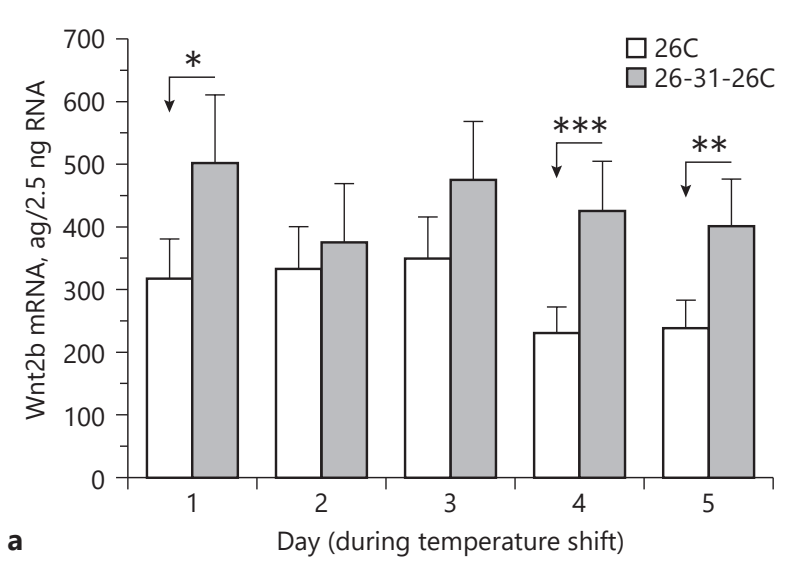

a

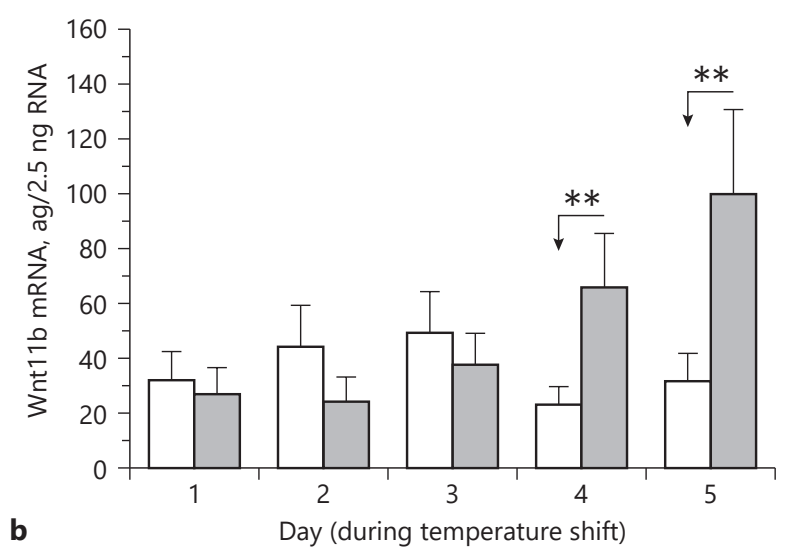

b

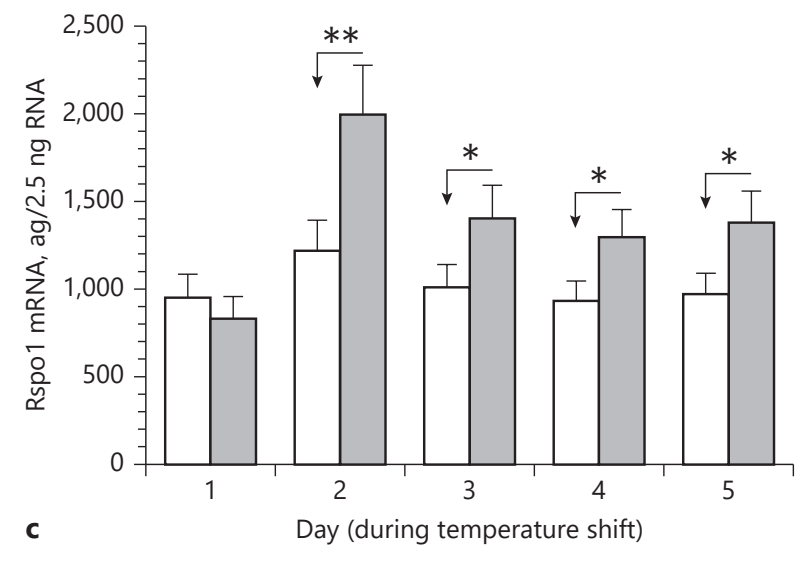

Fig. 5. Expression of $W n t 2 b$ (a), $W n t 11 b$ (b), and Rspo1 (c) mRNAs in embryonic snapping turtle gonads during the temperature sensitive period. Eggs were incubated at a male-producing temperature (26C) throughout embryogenesis or briefly shifted to a female-producing temperature (26-31-26C) when embryos reached stage 17. Embryos were sampled at the indicated times during the temperature shift. Expression levels are least squares means $( \pm 1$ $\mathrm{SE})$ for each temperature and time point. Arrows indicate significant differences between temperatures at the specified time and asterisks indicate level of significance. ${ }^{*} p<0.05,{ }^{* *} p<0.01,{ }^{* * *} p<$ 0.001 .

Wnt Signaling and Evolution in TSD percentage of GFP positive cells at the female temperature $(12.6 \pm 1.5 \%)$ than at the male temperature $(4.1 \pm$ $1.9 \%)$. Yet, there was no difference in CTCF between cells in replicate wells $\left(\mathrm{F}_{1,227}=0.04, p=0.84\right)$ or among regions within wells $\left(\mathrm{F}_{1,227}=0.67, p=0.75\right)$ at the same temperature. The percentage of GFP positive cells did not differ between replicate wells $\left(\mathrm{F}_{1,16}=1.88, p=0.19\right)$ or among regions within wells $\left(\mathrm{F}_{10,16}=1.09, p=0.42\right)$ at the same temperature.

Plates were returned to their original incubators for 2 more days. Temperature continued to have a significant effect on expression of the Wnt reporter after 4 days $\left(\mathrm{F}_{1,640}=17.6, p<0.0001\right)$, with greater CTCF in cells at the female-compared to cells at the male-producing temperature (Fig. 3a, b). In contrast to the 2-day time point, there were no differences in the percentage of GFP positive cells at the male-producing temperature $(16.6 \pm 1.8 \%)$ versus the female-producing temperature $(19.2 \pm 1.8 \%)$ after 4 days $\left(\mathrm{F}_{1,19}=1.10, p=0.31\right)$. The finding that the percentage of GFP positive cells increased from day 2 (4$13 \%)$ to day 4 (17-19\%) for both temperatures suggests gradual accumulation of GFP to a detectable level in transfected cells. Again, there was no difference in CTCF between cells in replicate wells $\left(\mathrm{F}_{1,640}=0.26, p=0.61\right)$ at the same temperature or among regions within wells $\left(\mathrm{F}_{1,640}=0.67, p=0.75\right)$. The percentage of GFP positive cells did not differ between replicate wells $\left(\mathrm{F}_{1,19}=1.01\right.$, $p=0.33)$ or among regions within wells $\left(\mathrm{F}_{10,19}=1.08, p=\right.$ 0.42 ). Together, these findings strongly suggest temperature-induced differences in Wnt signaling in bipotential gonadal cells in culture and that exposure of cells to a female-producing temperature induced a higher level of canonical Wnt signaling than exposure to a male-producing temperature.

In a second experiment, embryos were incubated at male- $\left(26.5^{\circ} \mathrm{C}\right)$ and female-producing $\left(31^{\circ} \mathrm{C}\right)$ temperatures throughout the thermosensitive period (from stage 17 until stage 20.3). After the sex-determining period, presumptive testes and ovaries were dissociated and the Wnt reporter was transfected into gonadal cells. Testicular and ovarian cells were plated separately and returned to their original incubators (i.e., male- or female-producing temperatures). There was a significant difference in expression of the Wnt reporter between testicular and ovarian cells 2 days after transfection $\left(\mathrm{F}_{1,256}=12.0, p=\right.$ $0.0006)$. CTCF was higher in ovarian cells at the femaleproducing temperature $(0.137 \pm 0.017)$ compared to testicular cells at the male-producing temperature $(0.080 \pm$ $0.010)$. However, there was no difference between testicular and ovarian cells in the percentage of cells with 
detectable GFP expression $\left(\mathrm{F}_{1,5}=0.9, p=0.39\right)$, indicating that transfection efficiency was similar in testicular and ovarian cells. There was no difference in CTCF between cells in replicate wells $\left(\mathrm{F}_{1,256}=1.74, p=0.19\right)$ or

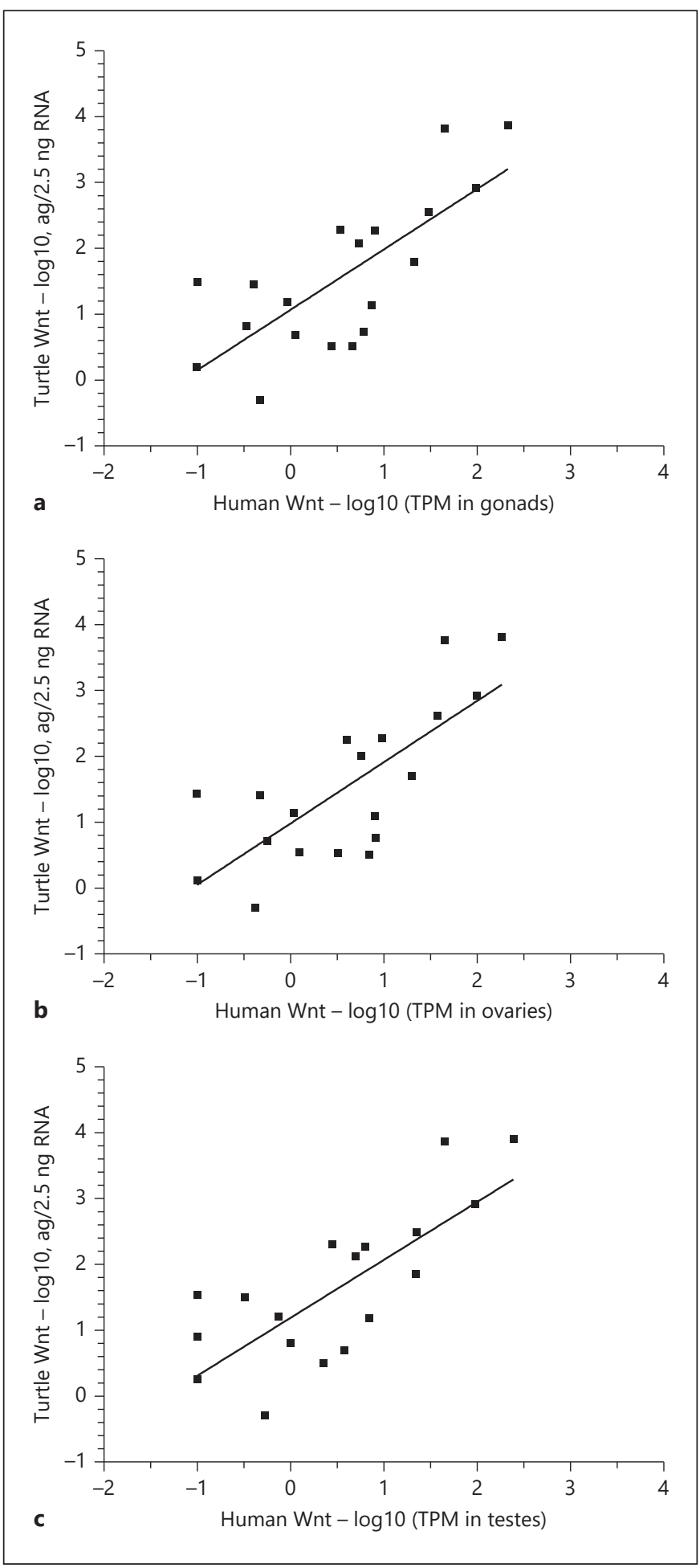

among cells in different region in wells $\left(\mathrm{F}_{4,256}=1.74, p=\right.$ $0.19)$. These results indicate that $\mathrm{Wnt}$ signaling was higher in differentiating ovarian cells than in differentiating testicular cells.

\section{Temperature Effects on Expression of Wnt Genes}

Next, we searched for Wnt ligands whose expression was compatible with the observed temperature effect on Wnt signaling. Temperature did not influence expression of 11 Wnt genes but did have a significant effect on expression of 9 Wnt genes (Table 2). For initial comparison of the overall magnitude and direction of the temperature effect, we divided average expression at the female-producing temperature by average expression at the maleproducing temperature. Effects were relatively small when averaged across all 5 days of the shift: Wnt1 $(0.80 \times)$, Wnt2b (1.37×), Wnt4 (0.81×), Wnt5a (0.82×), Wnt7a (0.57×), Wnt8a $(0.65 \times)$, Wnt9b (0.78×), Wnt11 (0.72×), and $W n t 11 b(1.26 \times)$. Expression of Wnt1, Wnt4, Wnt5a, $W n t 7 a, W n t 8 a, W n t 9 b$, and $W n t 11$ was significantly higher in gonads of embryos at $26.5^{\circ} \mathrm{C}$ versus embryos at $31^{\circ} \mathrm{C}$ (Fig. $4 \mathrm{a}-\mathrm{g}$ ). The temperature-by-day interaction affected $W n t 7 a$ expression (Table 2 ) with a significant difference between temperatures on day 2 of the shift (3.15fold higher expression at the male vs. the female temperature) but no difference on the other days. Conversely, $W n t 2 b$ expression was significantly higher (1.37-fold) in gonads of embryos at $31^{\circ} \mathrm{C}$ versus gonads of embryos at $26.5^{\circ} \mathrm{C}$ (Fig. $5 \mathrm{a}$ ), but there was no temperature-by-day interaction for $W n t 2 b$ (Table 2). There was a strong temperature-by-day interaction for Wnt $11 b$ expression (Table 2) with 3-fold higher expression in embryos at the female-producing temperature on days 4 and 5 of the shift, but not earlier (Fig. 5b). Both temperature and day influenced expression of Rspo1, but the temperature-byday interaction was not significant (Table 2) even though there appeared to be no difference on day 1 , a spike in

Fig. 6. Correlation between mRNA expression of Wnt orthologs in snapping turtle gonads and human gonads during the sex-determining period. Turtle Wnt1 expression is paired with human WNT1 expression, turtle Wnt2 is paired with human WNT2, turtle Wnt3 is paired with human WNT3, and so on. Expression in humans is measured in transcripts per million (TPM) from RNA-Seq studies. a Average expression in turtle gonads versus average expression in human gonads (overall average of ovarian and testicular expression across the sex-determining period). b Average expression in turtle gonads at a female-producing temperature versus expression in human gonads from genetic females. c Average expression in turtle gonads at a male-producing temperature versus expression in human gonads from genetic males.
Sex Dev 2021;15:47-68 DOI: $10.1159 / 000516973$
Rhen/Even/Brenner/Lodewyk/Das/Singh/ Simmons 
expression at the female temperature on day 2 , and smaller but significant differences on days 3-5 (Fig. 5c). When averaged across all 5 days, Rspo 1 expression was 1.88 -fold higher at the female-producing temperature than at the male-producing temperature (Fig. 5c). In sum, exposure of embryos to $31^{\circ} \mathrm{C}$ decreased expression of 7 Wnt genes but increased expression of $2 \mathrm{Wnt}$ genes and Rspol relative to embryos at $26.5^{\circ} \mathrm{C}$.

\section{Correlated Expression of Wnt Orthologs in Snapping \\ Turtle and Human Gonads}

Given that all Wnt genes were expressed at a detectable level in turtle gonads and that temperature influenced Wnt expression and Wnt signaling, we tested whether there was any relationship to expression of Wnt orthologs in human gonads. Average expression of Wnt genes in turtle embryonic gonads was correlated with average expression of their orthologs in human embryonic gonads
( $\rho=0.75, p=0.0002$; Fig. 6a). Expression levels of Wnt orthologs were also correlated in gonads that were developing into ovaries $(\rho=0.75, p=0.0002$; Fig. $6 \mathrm{~b})$ or into testes ( $\rho=0.75, p=0.0002$; Fig. $6 c$ ). These correlations were significant despite evolutionary changes in sexually dimorphic expression patterns during the sex-determining period. For instance, Wnt1, Wnt4, Wnt5a, Wnt7a, $W n t 9 b$, and $W n t 11$ were all sexually dimorphic in snapping turtle, but their orthologs were not dimorphic in human. Conversely, expression of Wnt3 and Wnt10a were not dimorphic in snapping turtle, while expression of WNT3 and WNT10A increased significantly in developing ovaries in human. Patterns were completely reversed for Wnt8a expression, which was higher at the male-producing temperature than at the female-producing temperature in turtle gonads. Expression of WNT8A increased significantly in developing ovaries but remained extremely low in developing testes in human. The only

Table 3. Results from BUSTED analyses of Wnt genes in vertebrates

\begin{tabular}{|c|c|c|c|c|c|}
\hline \multirow[t]{2}{*}{ Wnt1 } & \multirow[t]{2}{*}{$\mathrm{LR} \chi^{2}=10.8, p=0.001$} & Unconstrained & $0.00(1.70 \%)$ & $0.01(97.03 \%)$ & $7.92(1.27 \%)$ \\
\hline & & Constrained & $0.00(4.56 \%)$ & $0.00(90.11 \%)$ & $1.00(0.01 \%)$ \\
\hline \multirow[t]{2}{*}{ Wnt2 } & \multirow[t]{2}{*}{$\mathrm{LR} \chi^{2}=18.0, p=0.00002$} & Unconstrained & $0.00(8.55 \%)$ & $0.13(91.04 \%)$ & $32.72(0.41 \%)$ \\
\hline & & Constrained & $0.04(61.14 \%)$ & $0.05(26.76 \%)$ & $1.00(12.10 \%)$ \\
\hline \multirow[t]{2}{*}{$W n t 3 a$} & \multirow[t]{2}{*}{$\mathrm{LR} \chi^{2}=23.0, p<0.00001$} & Unconstrained & $0.01(92.74 \%)$ & $0.05(7.09 \%)$ & $127.00(0.17 \%)$ \\
\hline & & Constrained & $0.00(10.75 \%)$ & $0.00(86.38 \%)$ & $1.00(2.88 \%)$ \\
\hline \multirow[t]{2}{*}{ Wnt6 } & \multirow{2}{*}{$\mathrm{LR} \chi^{2}=9.8, p=0.0017$} & Unconstrained & $0.03(94.03 \%)$ & $0.03(2.08 \%)$ & $3.42(3.88 \%)$ \\
\hline & & Constrained & $0.01(2.00 \%)$ & $0.01(87.19 \%)$ & $1.00(10.81 \%)$ \\
\hline \multirow[t]{2}{*}{ Wnt9a } & \multirow{2}{*}{$\mathrm{LR} \chi^{2}=13.2, p=0.00028$} & Unconstrained & $0.00(96.57 \%)$ & $1.00(3.11 \%)$ & $65.31(0.33 \%)$ \\
\hline & & Constrained & $0.00(94.61 \%)$ & $1.00(0.71 \%)$ & $1.00(4.68 \%)$ \\
\hline \multirow[t]{2}{*}{ Wnt10a } & \multirow[t]{2}{*}{$\mathrm{LR} \chi^{2}=54.6, p<0.00001$} & Unconstrained & $0.00(13.12 \%)$ & $0.06(86.16 \%)$ & $154.28(0.72 \%)$ \\
\hline & & Constrained & $0.03(39.14 \%)$ & $0.03(54.16 \%)$ & $1.00(6.70 \%)$ \\
\hline \multirow[t]{2}{*}{ Wnt16 } & \multirow{2}{*}{$\mathrm{LR} \chi^{2}=13.0, p=0.0003$} & Unconstrained & $0.05(85.88 \%)$ & $1.00(13.99 \%)$ & $265.48(0.13 \%)$ \\
\hline & & Constrained & $0.04(83.66 \%)$ & $1.00(1.17 \%)$ & $1.00(15.17 \%)$ \\
\hline
\end{tabular}

Species with TSD were designated as foreground branches, while non-TSD species were designated as background branches. The statistical test compares the log likelihoods for an unconstrained model to a constrained model in the test branches. Both models have 3 rate classes for $d N / d S$ ratios $\left(\omega_{N}\right)$ with $\omega_{1} \leq \omega_{2} \leq \omega_{3}$ and $\omega_{3}=1$ for the null hypothesis (i.e., no positive selection) in the constrained model. Mean values for $\omega_{\mathrm{N}}$ are shown for the unconstrained and constrained models with the percentage of residues in each class within parentheses. 
Table 4. Results from MEME analyses of Wnt genes in vertebrates

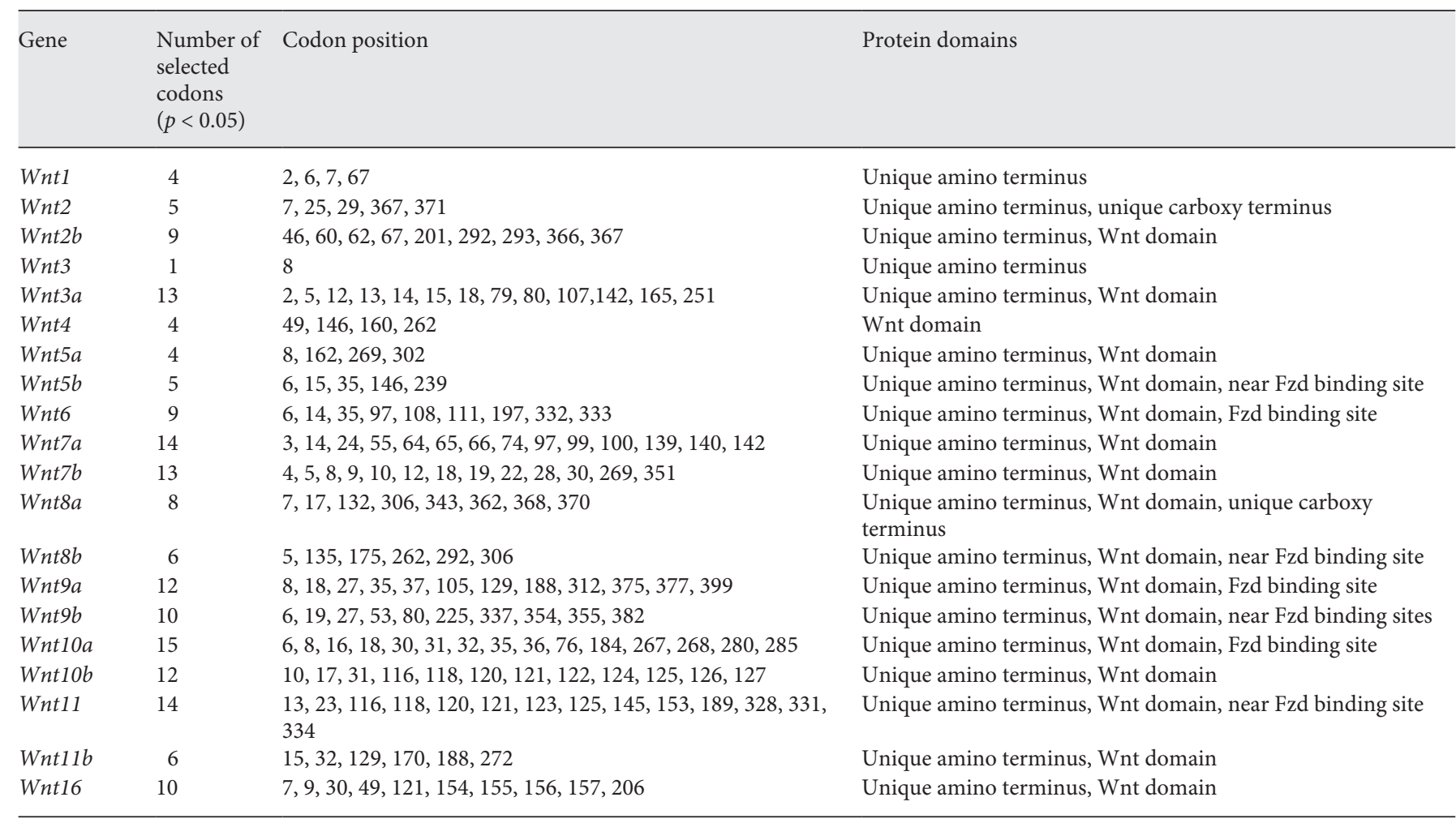

Individual sites are subject to positive selection. Codon position refers to the multiple sequence alignment. Protein domains specify the location of selected positions relative to functional domains within Wnt genes.

gene to display the same pattern of sexually dimorphic expression was $W n t 2 b$ in turtle and WNT2B in human (i.e., higher expression in developing ovaries than testes in both species). All remaining Wnt genes displayed monomorphic expression in turtles and humans. This raises the possibility of evolutionary shifts in which Wnt ligands play a role in sex determination and gonadal differentiation.

Molecular Evolution of Wnt Genes in TSD Vertebrates We therefore examined Wnt genes for evidence of positive selection in TSD vertebrates (foreground) while using non-TSD vertebrates as background. BUSTED revealed episodic diversifying selection for at least one site on at least one test branch for $10 \mathrm{Wnt}$ genes (Table 3). Likewise, aBSREL detected positive selection on $11 \mathrm{Wnt}$ genes and identified branches that have experienced positive selection (Table 1). Five Wnt genes displayed evidence of positive selection in tuatara (Wnt2, Wnt7b, Wnt9a, Wnt11, Wnt16). C. porosus or crocodilians as a group also exhibited evidence of selection for 3 of the same genes (Wnt2,
Wnt7b, Wnt9a). Other species only displayed evidence of positive selection on 1 or $2 \mathrm{Wnt}$ genes (Table 1).

Results from BUSTED and aBSREL were highly concordant $\left(\mathrm{LR} \chi^{2}=11.0, p=0.0009\right)$, with 17 of 20 genes either showing significant selection $(n=9)$ or no selection $(n=8)$ with both methods. The 2 methods produced discordant results for just 3 genes: Wnt 1 was only significant with BUSTED, while Wnt10b and Wnt11 were only significant with aBSREL. There was a tendency for Wnt genes that were thermosensitive in snapping turtle to be less likely to display evidence of positive selection in TSD species ( 2 of 9 genes or $22.2 \%$ ) than Wnt genes that were not thermosensitive ( 7 of 11 genes or 63.6\%) (Fisher's exact test, $p=0.08$ ).

This raised the possibility that thermosensitive Wnt genes might be more conserved than temperature insensitive Wnt genes. To test this hypothesis, we compared $d N / d S$ ratios for the first 2 rate classes $\left(\omega_{1}\right.$ and $\left.\omega_{2}\right)$ weighted by their frequency (i.e., $\omega_{\mathrm{N}}$ times proportion of codons in rate class $\mathrm{N}$ ) from the unconstrained BUSTED analyses. Repeated measures MANOVA indicated that there 


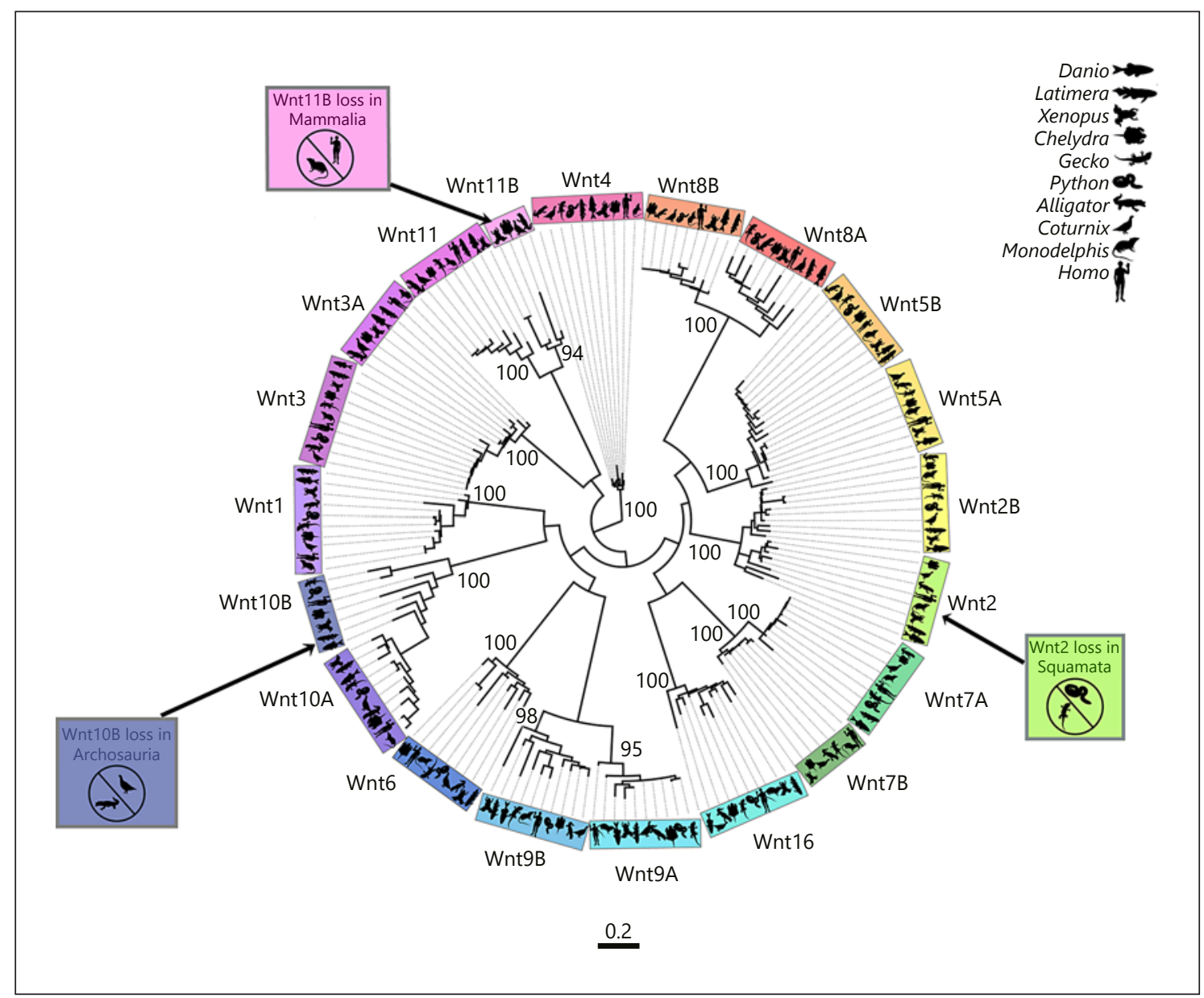

Fig. 7. Wnt gene family evolution in vertebrates. Boxes and arrows indicate lineage-specific losses of $W n t 11 b$ in mammals, Wnt $10 b$ in archosaurs, and Wnt2 in squamates.

was no difference between thermosensitive versus insensitive Wnt genes in the overall intensity of negative/neutral selection $\left(\omega_{1}+\omega_{2}\right)\left(F_{1,17}=0.84, p=0.37\right)$. However, the interaction between thermosensitivity and rate class was significant $\left(\mathrm{F}_{1,17}=5.17, p=0.036\right)$. Thermosensitive and insensitive Wnt genes had similar weighted $\omega_{1}$ (thermosensitive $=0.028 \pm 0.009$; insensitive $=0.016 \pm 0.008$ ), while weighted $\omega_{2}$ was lower in thermosensitive $\mathrm{Wnt}$ genes $(0.014 \pm 0.014)$ than in temperature insensitive Wnt genes $(0.047 \pm 0.012)$. This suggests stronger purifying selection has occurred on thermosensitive Wnt genes in TSD species.

We used MEME to further assess selection at individual sites in Wnt genes. Analysis of all Wnts revealed that numerous sites have been subject to episodic diversifying selection (Table 4). Most Wnt genes (19/20) had positively selected sites within their unique amino terminus, which is highly variable among Wnt paralogs. The majority of Wnt genes (16/20) also had positively selected sites within the Wnt domain. However, less than half of Wnt genes (7/20) had selected sites near or within Frizzled binding sites.

\section{Evolutionary Loss of Wnt Genes in Specific Vertebrate Lineages}

In retrieving and analyzing Wnt genes for evidence of selection, we also examined gene content in different vertebrate groups for loss of Wnt genes (Fig. 7). Wnt11b orthologs were not found in placental or marsupial mammals supporting the previously described evolutionary loss of Wnt $11 b$ in mammals. Wnt $10 b$ orthologs were not found in birds or crocodilians, which suggests Wnt10b was lost in archosaurs. Wnt 2 orthologs were not detected in lizards and snakes, but Wnt 2 was found in tuatara, sug- 
gesting specific $W n t 2$ loss in the squamate lineage after its divergence from the last common ancestor of lepidosaurs (lizards, snakes, and the tuatara).

\section{Discussion}

Here, we present evidence that Wnt expression and Wnt signaling in embryonic gonads differs between female- and male-producing temperatures in the snapping turtle, C. serpentina. Exposure of embryos to a femaleproducing temperature decreased expression of $7 \mathrm{Wnt}$ genes but increased expression of $2 \mathrm{Wnt}$ genes and Rspo 1 relative to embryos at a male-producing temperature. The finding that temperature also influenced expression of putative Wnt target genes indicates that differences in Wnt expression translated into differences in Wnt signaling in bipotential gonads. One of these genes, Axin2, is a well-characterized transcriptional target directly induced by canonical WNT/ $\beta$-catenin/TCF signaling [Jho et al., 2002]. Exposure of embryos to the female-producing temperature increased Axin 2 expression within $48 \mathrm{~h}$, suggesting that endogenous Wnt signaling in embryonic gonads is higher at a temperature that induces ovarian development versus one that induces testis development. This result is consistent with studies showing that Axin2 is activated during ovary determination in mice [Chassot et al., 2011, 2014; Jameson et al., 2012].

Like Axin2, Osr1 was upregulated by exposure of turtle embryos to the female-producing temperature. Osrl is a putative Wnt target because WNT3A ligand induces OSR1 expression within $4 \mathrm{~h}$ in human fibroblasts [KlapholzBrown et al., 2007]. Furthermore, Wnt signaling in combination with activin A and BMP signaling induces differentiation of human embryonic stem cells into bipotential gonad cells [Sepponen et al., 2017]. In that study, the most effective mix of signaling molecules induced expression of OSR 1 and other intermediate mesoderm markers before upregulating markers of bipotential gonad progenitors. In addition to its key role in urogenital formation from intermediate mesoderm in mice [Wang et al., 2005], Osr1 may be involved in granulosa cell development. Estermann et al. [2020] describe a bipotential progenitor cell population that is $\mathrm{Pax2}^{+} / \mathrm{Dmrt1}^{+} / \mathrm{Osrl}^{+} / \mathrm{Wnt}^{+}$in chicken gonads during sex determination. During ovary formation, this population loses Pax2, and cells differentiate into $\mathrm{Osr}^{+} / \mathrm{Foxl}^{+} / \mathrm{Cyp} 19 \mathrm{al} 1^{+}$pre-granulosa cells. A subset of these pre-granulosa cells lose Osr1, Foxl2, and Cyp19a1 expression and become thecal cells. During testis formation, Pax2, Osr1, and Wnt4 are all downregulated, where- as Dmrt1 levels increase. Together, those findings raise the possibility that maintenance of Osr1 expression is important for granulosa cell development.

Our finding that Vcan, another Wnt target [Rahmani et al., 2005], is expressed at a higher level at a male- versus a female-producing temperature is consistent with higher Vcan expression in XY supporting (pre-Sertoli) cells versus XX supporting (pre-granulosa) cells in mice [Piprek et al., 2018]. Versican is an extracellular matrix protein that can either have anti-adhesive or pro-adhesive effects on cells, depending upon the ratio of isoforms (VO, V1, V2, V3) [Rahmani et al., 2006; Mead et al., 2018]. Changes in Vcan expression may therefore play a part in cell migration, remodeling of the extracellular matrix and basement membrane, and morphogenesis of testis cords and ovarian cysts [Tilmann and Capel, 1999; Piprek et al., 2018].

Downregulation of Wnt target Btrc [Spiegelman et al., 2000] and $D k k 3$ at the female-producing temperature is interesting because these genes encode inhibitors of canonical Wnt signaling. Dickkopf proteins interact with LRP5/6 to inhibit Wnt activation of the frizzled-LRP5/6 co-receptor complex. Lower Dkk3 expression at femaleproducing temperatures could therefore contribute to higher Wnt signaling in turtle gonads, as observed with $D k k 3$ downregulation in cancer cells [Yue et al., 2008]. $\beta$-Transducin repeat containing E3 ubiquitin protein ligase (Btrc) ubiquitinates $\beta$-catenin and marks it for degradation by the proteasome. Again, downregulation of a Wnt pathway inhibitor (Btrc) could lead to higher Wnt signaling in gonads at the female temperature, as occurs with epigenetic silencing of Btrc in lung cancer [Tseng et al., 2008]. The combined effect of downregulation of 2 Wnt inhibitors could enhance even subtle differences in Wnt ligand expression and secretion at female-producing temperatures.

The inference that Wnt signaling is higher at femaleversus male-producing temperatures in the snapping turthe is supported by our studies of Wnt reporter activity in embryonic gonadal cells in vitro. Within $48 \mathrm{~h}$, expression of a canonical Wnt reporter containing 6 TCF/LEF response elements was significantly higher in primary cells at the female- versus the male-producing temperature. Higher expression of the Wnt reporter at the feminizing temperature was also observed on the 4 th day of the temperature shift. This experiment showed that primary cells from bipotential gonads respond directly to temperature, because cells were treated identically prior to the temperature shift (i.e., during in vivo incubation, tissue dissociation, and cell transfection). It also indicates that Wnt
Rhen/Even/Brenner/Lodewyk/Das/Singh/ Simmons 
signaling was higher at a temperature that induces ovary determination versus one that induces testis determination. A second experiment using primary cells collected at the very end of the sex-determining period also revealed higher Wnt reporter expression in presumptive ovarian versus testicular cells. Together, these results suggest that exposure to a feminizing temperature elevated Wnt signaling during specification (day 2 of the shift) and determination of ovarian fate (day 4 of the shift), as well as after ovarian fate had been determined (at stage 20.3). One caveat is that differences in Wnt reporter expression could be due to general temperature effects on transcription rather than specific activation of Wnt signaling. Future experiments could use the same plasmid with deleted TCF/LEF response elements or an unrelated control plasmid to test for general temperature effects on transcription.

Temperature-induced differences in $W n t 2 b$ and Rspo 1 expression and Wnt signaling emerged before changes in Foxl2 and Sox9 expression. This dynamic suggests that Wnt signaling may induce Foxl2 expression in the snapping turtle, just as constitutively active $\beta$-catenin induces Foxl2 in mice [Li et al., 2017]. At the same time, Wnt signaling could be repressing Sox 9 expression like pharmacological activation of $\beta$-catenin represses Sox9 in the red-eared slider turtle [Mork and Capel, 2013]. Indeed, $\beta$-catenin protein is found in both the cortical and medullary regions of bipotential gonads in red-eared slider turtles and is therefore in a position to regulate both genes [Mork and Capel 2013]. However, Wnt inhibition alone is not sufficient to derepress Sox 9 expression at a femaleproducing temperature in the red-eared slider turtle [Mork and Capel, 2013], suggesting that other factors are also involved in the inhibition of Sox9.

While it was fairly easy to show thermosensitive Wnt signaling and identify candidate Wnt signaling molecules, it will be much more difficult to definitively determine which Wnt ligand(s) differentially activates the canonical Wnt pathway in developing gonads. It is also possible that the non-canonical $\mathrm{Wnt} / \mathrm{Ca}^{+}$pathway could influence sex determination because calcium influx triggers STAT3 phosphorylation and inhibition of $K d m 6 b$ and Dmrt1 expression in the red-eared slider turtle [Weber et al., 2020]. Indeed, most Wnt ligands are capable of activating both canonical and non-canonical pathways [van Amerongen et al., 2008; Nie et al., 2020]. Expression profiles in bipotential gonads did not provide a clear-cut answer because temperature influenced expression of 9 Wnt genes and the magnitude of the temperature effect was relatively small. Larger effects were observed for

Wnt Signaling and Evolution in TSD
Wnt11b, which exhibited no differences on days $1-3$ of the temperature shift but much higher expression at the female-producing temperature on day 4 (2.84-fold) and day 5 (3.16-fold) of the shift. Thus, Wnt $11 b$ may contribute to ovary determination along with Wnt2b and Rspo1. The other $7 \mathrm{Wnt}$ genes were paradoxically expressed at a higher level at the male-producing temperature, making them weaker candidates. These rankings of Wnt candidates are tentative because differences in mRNA expression may not be tightly correlated with protein expression or secretion of mature ligands. Temperature could also have differential effects on maturation, sorting, and secretion of different Wnt proteins [Coudreuse and Korswagen, 2007].

Despite these caveats, subtle differences in Wnt mRNA expression can contribute to phenotypic variation in sex determination, even in species with sex chromosomes. Strain differences in susceptibility to XY sex reversal in mice are associated with differences in transcriptomewide patterns of gene expression in XY gonads on embryonic day 11.5 [Munger et al., 2009]. Males of the B6 strain (susceptible to XY sex reversal) exhibit a more female-like transcriptome, including higher Wnt4 (1.53-fold) and Wnt9a (1.69-fold) expression, than males of the 129S1 strain (resistant to XY sex reversal). A 1.53-fold difference in Wnt4 between strains seems small, but it may be biologically significant considering that the difference in Wnt4 expression between XX and XY gonads during the sex-determining period is only 3 -fold in mice [Chassot et al., 2008; Hiramatsu et al., 2009; Naillat et al., 2015; Li et al., 2017].

Our finding that sexual dimorphism in Wnt4 mRNA expression in bipotential gonads in the snapping turtle is reversed $(M>F)$ relative to mice $(F>M)$ suggests evolutionary changes in which Wnt gene(s) play a role in ovary determination. There are also differences between snapping turtles and humans in sexually dimorphic expression of several Wnt genes. Similar evolutionary divergence in expression patterns of Dmrt1, Wt1, Sf1, Dax1, Sox9, and Cyp19a1 during gonad development has been reported across vertebrates [Valenzuela et al., 2013; Mizoguchi and Valenzuela, 2020]. To our knowledge, there has not been a truly quantitative analysis of all Wnt genes in bipotential gonads in any species. Microarray and RNASeq studies provide semi-quantitative measurements of all expressed transcripts, but statistical analyses of these data typically use arbitrary cutoffs of 1.5- or 2-fold differences and adjust probability thresholds to control for false positives. These criteria inevitably cause false negatives for genes that display small but real differences. In 
fact, only 2 differentially expressed Wnt genes identified via $\mathrm{qPCR}$ in the snapping turtle would surpass an arbitrary 1.5-fold cutoff, and none would be detected with conservative corrections for multiple comparisons at a transcriptome-wide scale. Another problem with microarray and RNA-Seq studies is that their dynamic range is much smaller than qPCR. Ultra-deep sequencing would solve the dynamic range problem in RNA-Seq studies by producing more accurate measurements of lowly expressed transcripts.

While it is likely that expression differences have been underreported, a search of the literature still provides insight into the evolution of sexually dimorphic Wnt expression. We found 2 studies that used qPCR to measure expression of Wnt4 in one TSD turtle and 2 studies that used RNA-Seq to examine temperature effects on transcriptome-wide patterns of gene expression in 2 TSD reptiles. Using qPCR, Shoemaker et al. [2007] found no difference in Wnt4 expression between female and male temperatures in red-eared slider turtles during the thermosensitive period. However, Wnt4 expression is higher in differentiating ovaries versus testes after sex determination [Shoemaker et al., 2007]. Similarly, Mork and Capel [2013] found no difference in Wnt4 expression in redeared slider turtles until well after the sex had been determined: Wnt4 is higher in hatchling ovaries than hatchling testes. An RNA-Seq study also found no differences in Wnt4 expression in bipotential gonads of this species [Czerwinski et al., 2016]. Consistency among 3 studies gives a high degree of confidence that there is not a temperature effect on Wnt4 expression during the sex-determining period in slider turtles. Thus, there are at least 3 distinct patterns of sexual dimorphism for Wnt4 expression in bipotential gonads of amniotes: snapping turtles $(\mathrm{M}>\mathrm{F})$, red-eared slider turtles $(\mathrm{M}=\mathrm{F})$, and mice $(\mathrm{F}>$ $\mathrm{M})$.

We could not find studies that used qPCR to measure expression of other Wnt genes in embryonic gonads of TSD reptiles, but Czerwinski et al. [2016] and Yatsu et al. [2016] present RNA-Seq data that can be used for rough comparisons. Several genes in the slider turtle showed the same pattern as the snapping turtle, including Wnt $2 b$ (F $>\mathrm{M}), W n t 5 b(\mathrm{M}=\mathrm{F})$, and Wnt10a $(\mathrm{M}=\mathrm{F})$. Other genes diverged between these turtles. While Wnt5a was consistently male-biased across the thermosensitive period in snapping turtles, it was male-biased at one stage and female-biased at the next stage in slider turtles. Wnt6 was not differentially expressed in snapping turtles but was male-biased during the middle of the thermosensitive period in slider turtles. Wnt16 also differed between turtle species, with no temperature effect in snapping turtles but a female bias during the middle of the thermosensitive period in slider turtles.

Genes for Wnt11 and Wnt11b are a bit more problematic to compare because annotations in the original papers may not be correct. Two supplementary tables in Czerwinski et al. [2016] present conflicting data for a gene labeled Wnt11: one table shows no difference between temperatures, but the other shows female-biased expression across 5 developmental stages. Accession numbers were not provided, so it is not possible to compare sequences to determine if one table was referring to Wnt11 and the other to Wnt11b. In contrast, a gene labeled Wnt11 and one labeled "Protein Wnt-11-like, transcript variant X2" in the American alligator [Yatsu et al., 2016] refers to the same gene (i.e., Wnt11). The alligator Wnt11 gene was downregulated by shifting eggs from a femaleto a male-producing temperature. This is similar to our finding that $W n t 11 b$ is expressed at a lower level at a male-producing temperature in the snapping turtle. We suggest Wnt2b, Wnt11/Wnt11b, and Rspo1 may be the strongest candidates for playing a role in ovary specification and determination because they exhibit female-biased expression in bipotential gonads across TSD reptiles. Future studies should clearly identify which paralog, $W n t 11$ or Wnt11b, is being studied based on phylogenetic analysis of sequences.

We did not retrieve any Wnt $11 b$ orthologs in mammals, which confirms a prior report that this gene was lost in mammals [Kuraku and Kuratani, 2011]. It is interesting that loss of the $W n t 11 b$ gene is associated with a gain in female-biased Wnt4 expression in bipotential gonads in mammals. Perhaps Wnt11b was involved in ovary specification and determination in ancestral amniotes and Wnt 4 was involved in later stages of ovarian development, including maintenance of ovarian fate. In this scenario, a loss of $W n t 11 b$ would have required a heterochronic shift in sexually dimorphic Wnt4 expression to take over for $W n t 11 b$ in ovary determination.

We also discovered 2 new cases of gene loss in amniotes through an exhaustive search for Wnt orthologs. Many Wnt10a orthologs were found in birds and crocodilians, but we did not detect any Wnt10b orthologs, suggesting loss of Wnt10b in the last common ancestor of archosaurs. Knockout of Wnt10b in mice causes loss of bone mineral density [Stevens et al., 2010]. This raises an interesting hypothesis that loss of Wnt10b might have played a part in evolutionary changes in bone structure. We found $W n t 2 b$ orthologs in several lizards and a snake species but did not identify any Wnt 2 orthologs in these
Rhen/Even/Brenner/Lodewyk/Das/Singh/ Simmons 
groups. We did, however, find both $W n t 2$ and $W n t 2 b$ in the tuatara, which indicates that $W n t 2$ was present in the last common ancestor of lepidosaurs but was lost in squamates. The primary phenotype resulting from Wnt2 knockout in mice is abnormal placental vasculature and retarded embryonic and postnatal growth [van Amerongen and Berns, 2006]. The potential impact of Wnt2 loss in squamates is not obvious.

It is possible that $W n t 10 b$ and $W n t 2$ are only missing from archosaurs and squamates because of incomplete genome and/or transcriptome assemblies. Future studies could search for evidence of Wnt10b and Wnt2 in raw sequence data from archosaurs and squamates, respectively, or examine genome assemblies for gaps in the syntenic regions that contain these genes in other vertebrates. Another interesting area for studying is the evolution of thermosensitive expression with respect to gene duplications (i.e., Wnt2 and Wnt2b; Wnt11 and Wnt11b) and relaxed selection at transitions between TSD and GSD [Radhakrishnan et al., 2017, 2018].

Whatever the evolutionary history of Wnt loss and changes in Wnt expression, our observation that multiple Wnt genes are differentially expressed in bipotential gonads at female- versus male-producing temperatures suggests redundancy in Wnt signaling during sex determination. Chassot et al. [2014] proposed this idea in mice and noted that $W n t 2 b$ and $W n t 9 a$ are expressed in bipotential gonads and may activate Wnt signaling in the absence of Wnt4. Other research has shown sex differences in Wnt6 expression in mouse gonads during sex determination [Cederroth et al., 2007; Cory et al., 2007]. While it is understandable that studies have focused on Wnt4 since the first paper describing its role in ovary determination in mice [Vainio et al., 1999], a more systematic analysis of the role of other Wnt genes in sex determination is clearly warranted. Indeed, studies of human embryonic gonads do not detect sex differences in WNT4 expression during the sex-determining period [Mamsen et al., 2017; Cardoso-Moreira et al., 2020]. Wnt2b is of particular interest for further studies because it is the only Wnt gene that displays a conserved pattern of sexually dimorphic expression between snapping turtle, red-eared slider turtle, and human.

Expression of Wnt genes in snapping turtles is correlated with expression of their human orthologs, suggesting Wnt signaling plays a conserved role in gonad development in amniotes. However, differences in patterns of sexually dimorphic Wnt expression suggests evolutionary turnover in which Wnt ligands are involved in ovary development. Therefore, we hypothesized that Wnt cod- ing sequences might show evidence of selection related to the mode of sex determination. Unfortunately, there are not yet enough Wnt sequences available to compare evolutionary rates between TSD and GSD species while controlling for phylogeny. As a crude proxy for the mode of sex determination, we compared evolutionary rates between Wnt genes with thermosensitive expression to those that were not thermosensitive in the snapping turtle. Thermosensitive Wnts were somewhat less likely to show evidence of positive selection and to have experienced stronger purifying selection than thermally insensitive Wnts. Although there has not been a systematic evolutionary analysis of all $20 \mathrm{Wnt}$ genes prior to this study, Literman et al. [2018] reported that Wnt4 nucleotide and RSPO1 amino acid sequences tend to evolve faster at transitions between TSD and GSD. Overall, these findings are consistent with the idea that TSD was the ancestral state in amniotes [Pokorna and Kratochvil, 2016].

\section{Conclusion}

Here, we report that incubation temperature altered expression of several Wnt genes and their targets in bipotential gonads of snapping turtle embryos in vivo. Those results suggest that Wnt signaling is higher at a female-producing temperature than at a male-producing temperature, but the evidence is indirect. We therefore carried out in vitro experiments with a Wnt reporter to show that embryonic gonadal cells are thermosensitive and that Wnt signaling is indeed higher at a female- versus a male-producing temperature. We conclude that Wnt signaling is an evolutionarily conserved feature of ovarian development. Yet, accumulating evidence points to evolutionary turnover in the specific Wnt ligand(s) involved in different stages of gonad development from specification and determination of ovarian fate to maintenance of ovarian identity after sex determination. While it is not clear which Wnt signaling molecule is involved in TSD, the data presented here point to $W n t 2 b$, $W n t 11 b$, and Rspo 1 as leading candidates in the snapping turtle. We do not, however, exclude the possibility that multiple Wnt ligands play partially redundant or stagespecific roles in ovary specification, determination, and maintenance. Future studies of Wnt signaling in sex determination should expand beyond the historically narrow focus on Wnt4. 


\section{Acknowledgements}

The authors would like to thank Paige Goodman, Jon Heimler, Kevin Molinar, and Erika Scheibe for their help with gene expression and reporter gene studies. We also thank special editor Nicole Valenzuela and 2 anonymous reviewers for comments that helped improve the paper.

\section{Statement of Ethics}

Snapping turtle embryos were treated according to protocols 1509-4 and 1809-7C approved by the Institutional Animal Care and Use Committee (IACUC) at the University of North Dakota.

\section{Conflict of Interest Statement}

The authors have no conflicts of interest to declare.

\section{Funding Sources}

This work was supported with funding from the National Science Foundation of the United States (grant numbers IOS0923300, DBI-0959369, and IOS-1558034 to T.R. and DUE1742269 to R.S.). Support for undergraduate researchers A.B. and Z.E. was provided by the National Science Foundation grants DBI1852459 and DUE-1742269, respectively. D.D. was supported in part by the Pilot Postdoctoral Program at the University of North Dakota.

\section{Author Contributions}

T.R. conceived the studies, designed, and supervised the experiments, supervised and/or carried out data analyses, and wrote the manuscript. All authors read, edited, and approved the final manuscript. Z.E carried out most gene expression analyses. A.L. carried out and analyzed most reporter gene studies. A.B, D.D., S.S., and R.S. retrieved, trimmed, and aligned cDNA and amino acid sequences and carried out most evolutionary analyses.

\section{References}

Bachtrog D, Mank JE, Peichel CL, Kirkpatrick M, Otto SP, Ashman TL, et al. Sex determination: why so many ways of doing it? PLoS Biol. 2014;12:e1001899.

Barske LA, Capel B. Estrogen represses SOX9 during sex determination in the red-eared slider turtle Trachemys scripta. Dev Biol. 2010;341:305-14.

Brown CM. Fluorescence microscopy--avoiding the pitfalls. J Cell Sci. 2007;120:1703-5.

Bull JJ. Sex determination in reptiles. Q Rev Biol. 1980;55(1):3-21.

Capel B. Vertebrate sex determination: evolutionary plasticity of a fundamental switch. Nat Rev Genet. 2017;18:675-89.

Cardoso-Moreira M, Sarropoulos I, Velten B, Mort M, Cooper DN, Huber W, et al. Developmental gene expression differences between humans and mammalian models. Cell Rep. 2020;33:108308.

Cederroth CR, Pitetti JL, Papaioannou MD, Nef S. Genetic programs that regulate testicular and ovarian development. Mol Cell Endocrinol. 2007;265-266:3-9.

Chassot AA, Ranc F, Gregoire EP, Roepers-Gajadien HL, Taketo MM, Camerino G, et al. Activation of beta-catenin signaling by Rspol controls differentiation of the mammalian ovary. Hum Mol Genet. 2008;17:1264-77.

Chassot AA, Gregoire EP, Lavery R, Taketo MM, de RooijDG, AdamsIR, etal.RSPO1/ $\beta$-catenin signaling pathway regulates oogonia differentiation and entry into meiosis in the mouse fetal ovary. PLoS One. 2011;6:e25641.

Chassot AA, Gillot I, Chaboissier MC. R-spondin1, WNT4, and the CTNNB1 signaling pathway: strict control over ovarian differentiation. Reproduction. 2014;148:R97-110.
Chawengsaksophak K, Svingen T, Ng ET, Epp T, Spiller CM, Clark C, et al. Loss of Wnt5a disrupts primordial germ cell migration and male sexual development in mice. Biol Reprod. 2012;86:1-12.

Cory AT, Boyer A, Pilon N, Lussier JG, Silversides DW. Presumptive pre-Sertoli cells express genes involved in cell proliferation and cell signalling during a critical window in early testis differentiation. Mol Reprod Dev. 2007; 74:1491-504.

Coudreuse D, Korswagen HC. The making of Wnt: new insights into Wnt maturation, sorting and secretion. Development. 2007;134: 3-12.

Crews D. Temperature-dependent sex determination: the interplay of steroid hormones and temperature. Zoolog Sci. 1996;13:1-13.

Czerwinski M, Natarajan A, Barske L, Looger LL, Capel B. A timecourse analysis of systemic and gonadal effects of temperature on sexual development of the red-eared slider turtle Trachemys scripta elegans. Dev Biol. 2016; 420:166-77.

Darriba D, Taboada GL, Doallo R, Posada D. jModelTest 2: more models, new heuristics and parallel computing. Nat Methods. 2012; 9(8):772.

Das D, Singh SK, Bierstedt J, Erickson A, Galli GLJ, Crossley DA II, et al. Draft genome of the common snapping turtle, Chelydra serpentina, a model for phenotypic plasticity in reptiles. G3 (Bethesda). 2020;10:4299-314.

Devlin RH, Nagahama Y. Sex determination and sex differentiation in fish: An overview of genetic, physiological, and environmental influences. Aquaculture. 2002;208(3-4):191-364.
Estermann MA, Williams S, Hirst CE, Roly ZY, Serralbo O, Adhikari D, et al. Insights into gonadal sex differentiation provided by singlecell transcriptomics in the chicken embryo. Cell Rep. 2020;31:107491.

Ferrer-Vaquer A, Piliszek A, Tian G, Aho RJ, Dufort D, Hadjantonakis AK. A sensitive and bright single-cell resolution live imaging reporter of $\mathrm{Wnt} / \mathrm{B}$-catenin signaling in the mouse. BMC Dev Biol. 2010;10:121.

Fujimoto T, Ukeshima A, Miyayama Y, Horio F, Ninomiya E. Observations of primordial germ cells in the turtle embryo (Caretta caretta): light and electron microscopic studies. Dev Growth Differ. 1979;21(1):3-10.

Greenbaum E, Carr JL. Sexual differentiation in the spiny softshell turtle (Apalone spinifera), a species with genetic sex determination. J Exp Zool. 2001;290:190-200.

Guindon S, Gascuel O. A simple, fast, and accurate algorithm to estimate large phylogenies by maximum likelihood. Syst Biol. 2003;52: 696-704.

Hiramatsu R, Matoba S, Kanai-Azuma M, Tsunekawa N, Katoh-Fukui Y, Kurohmaru $\mathrm{M}$, et al. A critical time window of Sry action in gonadal sex determination in mice. Development. 2009;136:129-38.

Hubert J. Localisation extra-embryonnaire des gonocytes chez l'embryon d'orvet (Anguis fragilis L.]. Arch Anat Microsc Morphol Exp. 1971;60:261-8.

Hubert J. Ultrastructure des ebauches gonadiques du lezard vivipare (Lacerta vivipara jacquin) pendant le periode de colonization par les gonocytes. Arch Anat Microsc Morphol Exp. 1976;65:241-54. 
Jameson SA, Natarajan A, Cool J, DeFalco T, Maatouk DM, Mork L, et al. Temporal transcriptional profiling of somatic and germ cells reveals biased lineage priming of sexual fate in the fetal mouse gonad. PLoS Genet. 2012;8: e1002575.

Janzen FJ, Paukstis GL. Environmental sex determination in reptiles: Ecology, evolution, and experimental design. Q Rev Biol. 1991;66: $149-79$.

Jho EH, Zhang T, Domon C, Joo CK, Freund JN, Costantini F. Wnt/beta-catenin/Tcf signaling induces the transcription of Axin2, a negative regulator of the signaling pathway. Mol Cell Biol. 2002;22:1172-83.

Klapholz-Brown Z, Walmsley GG, Nusse YM, Nusse R, Brown PO. Transcriptional program induced by Wnt protein in human fibroblasts suggests mechanisms for cell cooperativity in defining tissue microenvironments. PLoS One. 2007;2:e945.

Komiya Y, Habas R. Wnt signal transduction pathways. Organogenesis. 2008;4:68-75.

Kuraku S, Kuratani S. Genome-wide detection of gene extinction in early mammalian evolution. Genome Biol Evol. 2011;3:1449-62.

Lance VA. Is regulation of aromatase expression in reptiles the key to understanding temperature-dependent sex determination? J Exp Zool A Ecol Genet Physiol. 2009;311:314-22.

Larkin MA, Blackshields G, Brown NP, Chenna $\mathrm{R}, \mathrm{McGettigan} \mathrm{PA,} \mathrm{McWilliam} \mathrm{H,} \mathrm{et} \mathrm{al.} \mathrm{Clust-}$ al $\mathrm{W}$ and Clustal $\mathrm{X}$ version 2.0. Bioinformatics. 2007;23:2947-8.

Li Y, Zhang L, Hu Y, Chen M, Han F, Qin Y, et al. $\beta$-Catenin directs the transformation of testis Sertoli cells to ovarian granulosa-like cells by inducing Foxl2 expression. J Biol Chem. 2017; 292:17577-86.

Literman R, Burrett A, Bista B, Valenzuela N. Putative independent evolutionary reversals from genotypic to temperature-dependent sex determination are associated with accelerated evolution of sex-determining genes in turtles. J Mol Evol. 2018;86:11-26.

Liu CF, Bingham N, Parker K, Yao HH. Sex-specific roles of beta-catenin in mouse gonadal development. Hum Mol Genet. 2009;18:40517.

Loffler KA, Koopman P. Charting the course of ovarian development in vertebrates. Int J Dev Biol. 2002;46:503-10.

Maatouk DM, DiNapoli L, Alvers A, Parker KL, Taketo MM, Capel B. Stabilization of betacatenin in XY gonads causes male-to-female sex-reversal. Hum Mol Genet. 2008;17:294955.

Mamsen LS, Ernst EH, Borup R, Larsen A, Olesen $\mathrm{RH}$, Ernst E, et al. Temporal expression pattern of genes during the period of sex differentiation in human embryonic gonads. Sci Rep. 2017;7:15961.

Mead TJ, Du Y, Nelson CM, Gueye NA, Drazba J, Dancevic CM, et al. ADAMTS9-regulated pericellular matrix dynamics governs focal adhesion-dependent smooth muscle differentiation. Cell Rep. 2018;23:485-98.
Merchant-Larios H, Ruiz-Ramirez S, MorenoMendoza N, Marmolejo-Valencia A. Correlation among thermosensitive period, estradiol response, and gonad differentiation in the sea turtle Lepidochelys olivacea. Gen Comp Endocrinol. 1997;107:373-85.

Merchant-Larios H, Díaz-Hernández V, Marmolejo-Valencia A. Gonadal morphogenesis and gene expression in reptiles with temperature-dependent sex determination. Sex Dev. 2010;4:50-61.

Miller MA, Pfeiffer W, Schwartz T. Creating the CIPRES Science Gateway for inference of large phylogenetic trees. Gateway Computing Environments Workshop (GCE).2010;1-8.

Mizoguchi B, Valenzuela N. Alternative splicing and thermosensitive expression of Dmrt1 during urogenital development in the painted turtle, Chrysemys picta. PeerJ. 2020;8:e8639.

Mork L, Capel B. Conserved action of $\beta$-catenin during female fate determination in the redeared slider turtle. Evol Dev. 2013;15:96-106.

Morrish BC, Sinclair AH. Vertebrate sex determination: many means to an end. Reproduction. 2002; 124:447-57.

Munger SC, Aylor DL, Syed HA, Magwene PM, Threadgill DW, Capel B. Elucidation of the transcription network governing mammalian sex determination by exploiting strain-specific susceptibility to sex reversal. Genes Dev. 2009;23:2521-36

Murrell B, Wertheim JO, Moola S, Weighill T, Scheffler K, Kosakovsky Pond SL. Detecting individual sites subject to episodic diversifying selection. PLoS Genet. 2012;8:e1002764.

Murrell B, Weaver S, Smith MD, Wertheim JO, Murrell S, Aylward A, et al. Gene-wide identification of episodic selection. Mol Biol Evol. 2015;32:1365-71

Naillat F, Yan W, Karjalainen R, Liakhovitskaia A, Samoylenko A, Xu Q, et al. Identification of the genes regulated by Wnt-4, a critical signal for commitment of the ovary. Exp Cell Res. 2015;332:163-78

Nie X, Liu H, Liu L, Wang YD, Chen WD. Emerging roles of Wnt ligands in human colorectal cancer. Front Oncol. 2020;10:1341.

Ottolenghi C, Pelosi E, Tran J, Colombino M, Douglass E, Nedorezov T, et al. Loss of Wnt4 and Foxl2 leads to female-to-male sex reversal extending to germ cells. Hum Mol Genet. 2007; 16:2795-804.

Pannetier M, Chassot AA, Chaboissier MC, Pailhoux E. Involvement of FOXL2 and RSPO1 in ovarian determination, development, and maintenance in mammals. Sex Dev. 2016;10: $167-84$.

Pieau C, Dorizzi M. Oestrogens and temperaturedependent sex determination in reptiles: all is in the gonads. J Endocrinol. 2004;181:367-77.

Piprek RP, Kolasa M, Podkowa D, Kloc M, Kubiak JZ. Transcriptional profiling validates involvement of extracellular matrix and proteinase genes in mouse gonad development. Mech Dev. 2018;149:9-19.
Pokorna MJ, Kratochvil L. What was the ancestral sex-determining mechanism in amniote vertebrates? Biol Rev Camb Philos Soc. 2016;91: $1-12$.

Radhakrishnan S, Literman R, Neuwald J, Severin A, Valenzuela N. Transcriptomic responses to environmental temperature by turtles with temperature-dependent and genotypic sex determination assessed by RNAseq inform the genetic architecture of embryonic gonadal development. PLoS One. 2017;12:e0172044.

Radhakrishnan S, Literman R, Neuwald JL, Valenzuela $\mathrm{N}$. Thermal response of epigenetic genes informs turtle sex determination with and without sex chromosomes. Sex Dev. 2018;12:308-19.

Rahmani M, Read JT, Carthy JM, McDonald PC, Wong BW, Esfandiarei M, et al. Regulation of the versican promoter by the beta-catenin- $\mathrm{T}$ cell factor complex in vascular smooth muscle cells. J Biol Chem. 2005;280:13019-28.

Rahmani M, Wong BW, Ang L, Cheung CC, Carthy JM, Walinski $\mathrm{H}$, et al. Versican: signaling to transcriptional control pathways. Can J Physiol Pharmacol. 2006;84:77-92.

Ramsey M, Crews D. Steroid signaling and temperature-dependent sex determination. Reviewing the evidence for early action of estrogen during ovarian determination in turtles. Semin Cell Dev Biol. 2009;20:283-92.

Raynaud A, Pieau C. Embryonic development of the genital system. In: Billett F, Gans C, editors. Biology of the Reptilia Volume 15: Development B. New York: Wiley and Sons; 1985. p. 149-300.

Rhen T, Lang JW. Temperature-dependent sex determination in the snapping turtle: manipulation of the embryonic sex steroid environment. Gen Comp Endocrinol. 1994;96:24354.

Rhen T, Lang JW. Among-family variation for environmental sex determination in reptiles. Evolution. 1998;52:1514-20.

Rhen T, Schroeder A. Molecular mechanisms of sex determination in reptiles. Sex Dev. 2010; 4:16-28.

Rhen T, Metzger K, Schroeder A, Woodward R. Expression of putative sex-determining genes during the thermosensitive period of gonad development in the snapping turtle, Chelydra serpentina. Sex Dev. 2007;1:255-70.

Rhen T, Fagerlie R, Schroeder A, Crossley DA II, Lang JW. Molecular and morphological differentiation of testes and ovaries in relation to the thermosensitive period of gonad development in the snapping turtle, Chelydra serpentina. Differentiation. 2015;89:31-41.

Sekido R, Lovell-Badge R. Genetic control of testis development. Sex Dev. 2013;7:21-32.

Sepponen K, Lundin K, Knuus K, Väyrynen P, Raivio T, Tapanainen JS, et al. The role of sequential BMP signaling in directing human embryonic stem cells to bipotential gonadal cells. J Clin Endocrinol Metab. 2017;102: 4303-14. 
Shoemaker CM, Crews D. Analyzing the coordinated gene network underlying temperaturedependent sex determination in reptiles. Semin Cell Dev Biol. 2009;20:293-303.

Shoemaker CM, Queen J, Crews D. Response of candidate sex-determining genes to changes in temperature reveals their involvement in the molecular network underlying temperature-dependent sex determination. Mol Endocrinol. 2007;21:2750-63.

Smith CA, Joss JMP. Gonadal sex differentiation in Alligator mississippiensis, a species with temperature-dependent sex determination. Cell Tissue Res. 1993;273(1):149-62.

Smith CA, Shoemaker CM, Roeszler KN, Queen J, Crews D, Sinclair AH. Cloning and expression of R-Spondin 1 in different vertebrates suggests a conserved role in ovarian development. BMC Dev Biol. 2008;8:72.

Smith MD, Wertheim JO, Weaver S, Murrell B, Scheffler K, Kosakovsky Pond SL. Less is more: an adaptive branch-site random effects model for efficient detection of episodic diversifying selection. Mol Biol Evol. 2015;32: 1342-53.

Spiegelman VS, Slaga TJ, Pagano M, Minamoto T, Ronai Z, Fuchs SY. Wnt/beta-catenin signaling induces the expression and activity of betaTrCP ubiquitin ligase receptor. Mol Cell. 2000;5:877-82.

Stamatakis A. RAxML Version 8: a tool for phylogenetic analysis and post-analysis of large phylogenies. Bioinformatics. 2014;30:1312-3.

Stevens JR, Miranda-Carboni GA, Singer MA, Brugger SM, Lyons KM, Lane TF. Wnt10b deficiency results in age-dependent loss of bone mass and progressive reduction of mesenchymal progenitor cells. J Bone Miner Res. 2010; 25:2138-47.
Tevosian SG. Genetic control of ovarian development. Sex Dev. 2013;7:33-45.

Tilmann C, Capel B. Mesonephric cell migration induces testis cord formation and Sertoli cell differentiation in the mammalian gonad. Development. 1999;126:2883-90.

Tseng RC, Lin RK, Wen CK, Tseng C, Hsu HS, Hsu WH, et al. Epigenetic silencing of AXIN2/ betaTrCP and deregulation of p53-mediated control lead to wild-type beta-catenin nuclear accumulation in lung tumorigenesis. Oncogene. 2008;27:4488-96.

van Amerongen R, Berns A. Knockout mouse models to study Wnt signal transduction. Trends Genet. 2006;22:678-89.

van Amerongen R, Mikels A, Nusse R. Alternative Wnt signaling is initiated by distinct receptors. Sci Signal. 2008;1:re9.

Vainio S, Heikkilä M, Kispert A, Chin N, McMahon AP. Female development in mammals is regulated by Wnt-4 signalling. Nature. 1999; 397:405-9.

Valenzuela N. Introduction. In: Valenzuela N, Lance VA, editors. Temperature-Dependent Sex Determination in Vertebrates. Washington D.C.: Smithsonian Institution; 2004. p. $1-4$.

Valenzuela N, Neuwald JL, Literman R. Transcriptional evolution underlying vertebrate sexual development. Dev Dyn. 2013;242:30719.

Wang Q, Lan Y, Cho E-S, Maltby KM, Jiang R. Odd-skipped related 1 (Odd1) is an essential regulator of heart and urogenital development. Dev Biol. 2005;288:582-94.
Weaver S, Shank SD, Spielman SJ, Li M, Muse SV, Kosakovsky Pond SL. Datamonkey 2.0: A modern web application for characterizing selective and other evolutionary processes. Mol Biol Evol. 2018;35:773-7.

Weber C, Zhou Y, Lee JG, Looger LL, Qian G, Ge $\mathrm{C}$, et al. Temperature-dependent sex determination is mediated by pSTAT3 repression of Kdm6b. Science. 2020;368:303-6.

Wernersson R, Pedersen AG. RevTrans: Multiple alignment of coding DNA from aligned amino acid sequences. Nucleic Acids Res. 2003; 31:3537-9.

Wibbels T, Bull JJ, Crews D. Chronology and morphology of temperature-dependent sex determination. J Exp Zool. 1991;260:371-81.

Wilhelm D, Palmer S, Koopman P. Sex determination and gonadal development in mammals. Physiol Rev. 2007;87:1-28.

Willert J, Epping M, Pollack JR, Brown PO, Nusse R. A transcriptional response to Wnt protein in human embryonic carcinoma cells. BMC Dev Biol. 2002;2:8.

Witschi E. Gonad development and function embryogenesis of the adrenal and the reproductive glands. Recent Prog Horm Res. 1951; $6: 1-27$.

Yatsu R, Miyagawa S, Kohno S, Parrott BB, Yamaguchi K, Ogino Y, et al. RNA-Seq analysis of the gonadal transcriptome during Alligator mississippiensis temperature-dependent sex determination and differentiation. BMC Genomics. 2016;17:77.

Yntema CL. A series of stages in the embryonic development of Chelydra serpentina. J Morphol. 1968;125:219-51.

Yue W, Sun Q, Dacic S, Landreneau RJ, Siegfried JM, Yu J, et al. Downregulation of Dkk3 activates beta-catenin/TCF-4 signaling in lung cancer. Carcinogenesis. 2008;29:84-92. 